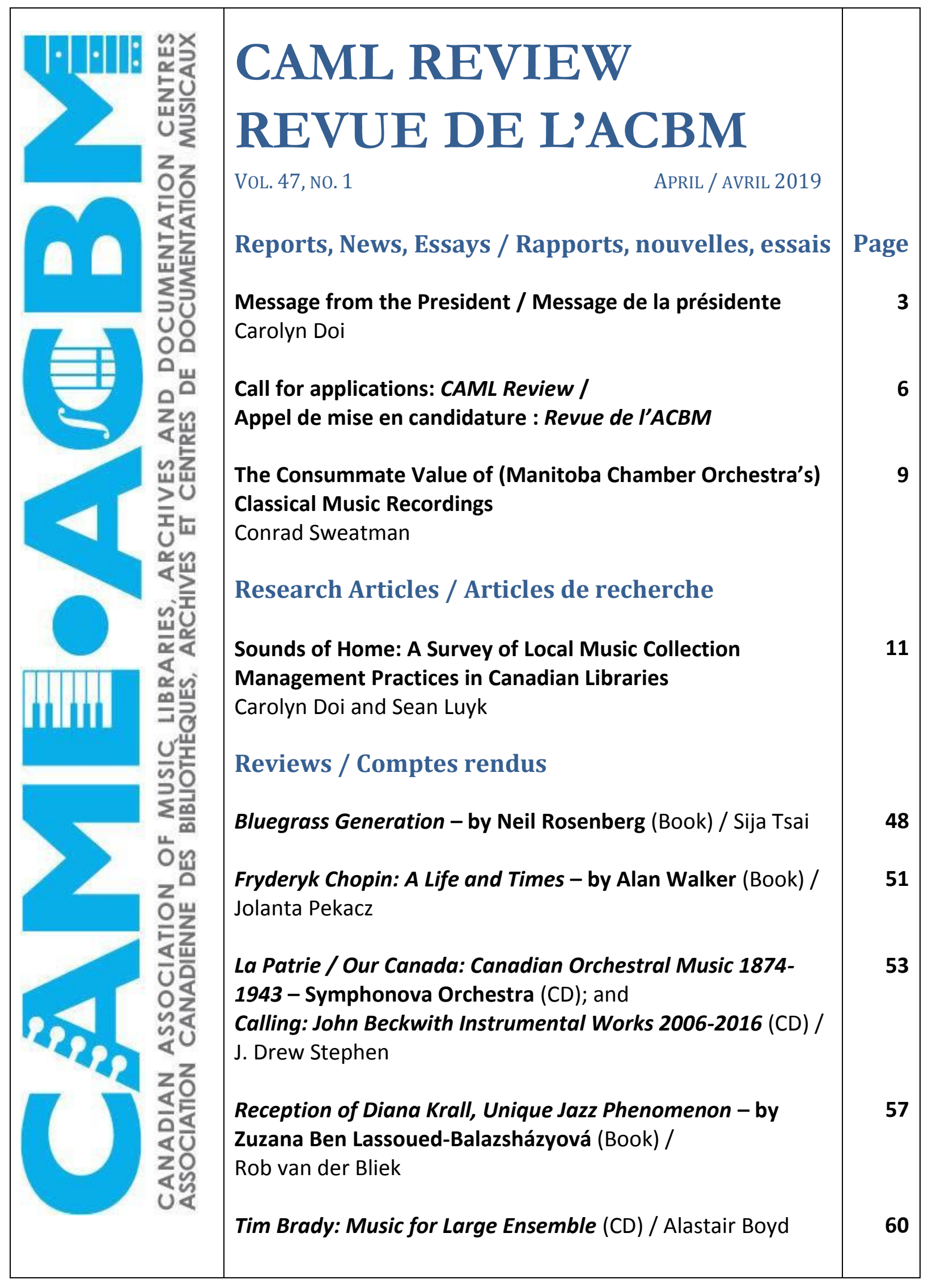


CAML Review, published three times a year, is the official publication of the Canadian Association of Music Libraries, Archives and Documentation Centres. CAML Review welcomes submissions of research articles (peer-reviewed section), reports, news, essays, and reviews on topics relevant to the purposes of the Association, particularly those pertaining to music in Canada, music librarianship and archival management, and bibliography. Author guidelines can be consulted on the journal site.

La Revue de l'ACBM, publiée trois fois l'an, est l'organe officiel de l'Association canadienne des bibliothèques, archives et centres de documentation musicaux. La Revue de l'ACBM vous invite à lui soumettre des articles de recherche (pour la section d'articles évalués par des pairs), des rapports, des nouvelles, des essais et des comptes rendus portant sur des sujets pertinents aux objectifs de l'Association, en particulier ceux qui traitent de la musique au Canada, de la bibliothéconomie et la gestion d'archives de la musique, ainsi que la bibliographie. On peut lire les directives aux auteurs sur le site de la Revue.

Editor / Rédactrice en chef :

Cathy Martin, Marvin Duchow Music Library, McGill University, Montreal, Quebec, H3A 1 E3. Tel: 514-398-5874; cathy.martin@mcgill.ca

\section{Associate Editors / Rédactrices adjointes :}

Megan Chellew, Collection Services, McGill University Library, Montreal, Quebec, H3A OC9.

Tel: 514-398-4174; megan.chellew@mcgill.ca

Deborah Wills, Librarian Emeritus, Wilfrid Laurier University, Waterloo, Ontario; dwills@wlu.ca

\section{Review Editor / Responsable des comptes-rendus :}

Brian C. Thompson, Department of Music, The Chinese University of Hong Kong, Shatin, NT, Hong Kong SAR, China. Tel: 852-3943-4220; thompson@cuhk.edu.hk

CAML Membership Secretary / Secrétaire aux adhesions de l'ACBM :

Becky Smith, Music Resource Centre, Memorial University of Newfoundland, St John's, Newfoundland, A1C 5S7.Tel: 709-864-7829; becky.smith@mun.ca

Advertising / Publicité : Please contact the Editors. / Veuillez communiquer avec les rédacteurs.

CAML Review / Revue de l'ACBM : http://caml.journals.yorku.ca

CAML / ACBM : https://www.caml-acbm.org

Section québécoise de l'ACBM / Quebec Chapter of CAML : http://www.sqacbm.org

(C) 2019 Canadian Association of Music Libraries, Archives and Documentation Centres / Association canadienne des bibliothèques, archives et centres de documentation musicaux 


\section{Message from the President / Message de la présidente}

Dear CAML members,

Greetings from Saskatoon! I can hardly believe it is the last time I will be writing the President's Message. It has been my pleasure to serve in this position for the past two years. I want to express my gratitude and thanks to all the members of the board who have worked alongside me during my term, and I look forward to welcoming my colleague Houman Behzadi to take over the position this June.

The board recently held its spring meeting, during which we discussed plans for the upcoming meeting in Vancouver at the University of British Columbia, as well as several shifts in responsibilities. Marc Stoeckle (Program Committee Chair) and Kevin Madill (Local Arrangements Chair) have been hard at work planning the upcoming annual meeting, along with colleagues in MusCan. The preliminary program has now been posted to the Congress website (https://www.congress2019.ca/associatio

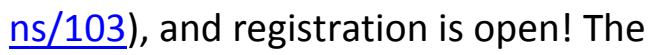
program looks both engaging and diverse. I am especially looking forward to the presentation and panel discussion titled "Music Scholarship and Digital

Technologies: Perspectives from Collaborative Corpus Building and Text Analysis," which will be presented by Ève Poudrier and Rémi Castonguay from the University of British Columbia. Vancouver and UBC will certainly be a beautiful backdrop for the meeting, but you might want to bring a rain jacket just in case! You can expect to see updates about
Chers membres de l'ACBM,

Bonjour de Saskatoon! J'ai de la peine à croire que je rédige le Message de la présidente pour la dernière fois. C'est avec plaisir que j'ai tenu ce rôle pendant deux ans. Je remercie tous les membres du CA de leur collaboration au cours de mon mandat et je me réjouis d'accueillir le futur président, mon collègue Houman Behzadi, qui prendra la relève dès le mois de juin.

Le $C A$ a récemment tenu sa réunion du printemps. Nous y avons discuté de l'organisation du congrès qui se tiendra à I'Université de la Colombie-Britannique, à Vancouver, ainsi que de plusieurs transferts de responsabilités. Marc Stoeckle (responsable de la programmation du congrès) et Kevin Madill (responsable des préparatifs sur place) ainsi que nos collègues de MusCan ont travaillé d'arrache-pied pour planifier cette réunion annuelle. On a affiché l'ébauche du programme sur le site du congrès : https://www.congres2019.ca/associations/1 $\underline{03}$, et il est maintenant possible de s'inscrire. Le programme est à la fois diversifié et intéressant. La présentation d'Ève Poudrier et de Rémi Castonguay, de I'Université de la Colombie-Britannique, m'enthousiasme particulièrement : « Érudition musicale et technologies numériques : constitution collaborative d'un corpus et réalisation d'une analyse de texte ". Celle-ci sera suivie d'une table ronde. Vancouver et l'université serviront de merveilleux arrière-plan à ce congrès, mais n'oubliez pas d'apporter un imperméable! Nous vous ferons parvenir sur notre serveur 
social events and places to explore via the CAML listserv.

The board has welcomed some new faces to appointed and volunteer positions. Kyla Jemison (University of Toronto) was appointed to the position of Nominations Officer and is running the current call for nominations for the position of Secretary. Marc Stoeckle has been volunteering to assist James Mason with the CAML website. I anticipate a draft of a newly designed site will be shared during our upcoming AGM. Finally, we have had some recent development with RISM responsibilities. Creighton Barrett (Dalhousie University) has done some significant work on adding Canadian music manuscripts and first edition publications to RISM. You can read all about the sources, as well as some new documentation that has been developed by Dalhousie, on the RISM blog (http://www.rism.info/en/home/newsdet ails/article/2/new-sources-from-canadain-rism.html). The position of RISM coordinator has been vacant for some time, but I am happy to report that Kyla Jemison has agreed to take on the position. Kyla's expertise with MarcEdit and cataloguing will undoubtedly be an asset in this role.

This issue of CAML Review features one peer-reviewed article, a report about the Manitoba Chamber Orchestra's record label, MCO Records, and several reviews. We are anticipating significant changes on the editorial board of the Review, as both Cathy Martin (Editor) and Brian Thompson (Review Editor) have announced they will be stepping down in the upcoming year. $A$ call for both positions has been posted to the CAML listserv and also appears in this de liste des suggestions d'activités et d'endroits à visiter.

Le CA a accueilli de nouveaux bénévoles et pourvu certains postes. Kyla Jemison (Université de Toronto) a été nommée responsable des mises en candidature. D'ailleurs, celle-ci a déjà affiché le poste de secrétaire à combler. Depuis quelque temps, Marc Stoeckle aide à titre gracieux James Mason à l'entretien du site Web. Je m'attends à ce qu'ils soumettent à l'AGA une version renouvelée du site Web. Enfin, il y a du nouveau sur le plan du RISM. Creighton Barrett (Université Dalhousie) a ajouté au RISM beaucoup de manuscrits de musique canadienne ainsi que des éditions originales de publications. On peut en apprendre davantage sur les sources et la documentation qu'a accumulées I'Université Dalhousie en se rendant à l'adresse : http://www.rism.info/fr/home/newsdetails/ article/2/new-sources-from-canada-inrism.html (en anglais seulement). Le poste de coordonnateur pour le RISM est vacant depuis un certain temps, mais je suis heureuse de vous faire savoir que Kyla Jemison a accepté de le pourvoir. L'expertise de Kyla en matière de catalogage et son expérience avec MarcEdit constitueront assurément des atouts dans l'exercice de ses fonctions.

Le présent numéro de la Revue de l'ACBM contient un article évalué par les pairs, un rapport portant sur l'étiquette $\mathrm{MCO}$ Records, de la Manitoba Chamber Orchestra, ainsi que plusieurs comptes rendus. De grands changements se produiront au sein du comité de rédaction de la Revue. Cathy Martin (rédactrice en chef) et Brian Thompson (responsable des comptes rendus) nous ont annoncé qu'ils quitteront leurs fonctions au cours de 
issue. If you are interested in contributing to the important work of our association's official publication-to support communication and professional knowledge sharing among members, and to promote the dissemination of scholarship-please reach out to any member of the board. Cathy and Brian have offered to provide support, during the transition, to the candidates who take over the positions.

It is always encouraging and exciting to hear about the work of my colleagues, whether it be through the CAML Review, via the listserv, or in person. The CAML community continues to be one that I am inspired by regularly. I look forward to staying on in the role of Past President for the upcoming year and hope to see many of you in Vancouver.

Carolyn Doi

CAML President (2017-19)

University of Saskatchewan

carolyn.doi@usask.ca l'année. Un appel de mise en candidature pour leurs postes a paru sur notre serveur de liste et est inclus dans ce numéro. Si vous souhaitez contribuer à la parution de notre publication officielle, en soutenant la communication entre membres, leurs échanges professionnels et la diffusion des connaissances, veuillez en notifier l'un des membres du CA. Cathy et Brian ont offert d'aider les candidats choisis pendant leur période de transition.

Il est toujours encourageant et enthousiasmant d'entendre parler du travail de mes collègues, que ce soit au moyen de la Revue de l'ACBM, du serveur de liste ou de dialogues. La collectivité de l'ACBM ne cesse de $m^{\prime}$ inspirer. Je me réjouis d'occuper le poste d'ancienne présidente au cours de l'année qui vient et j'espère vous voir nombreux à Vancouver!

Carolyn Doi

Présidente de l'ACBM (2017-2019)

Université de la Saskatchewan

carolyn.doi@usask.ca

Traduction : Marie-Marthe Jalbert

Révision : Valérie Arboit 


\section{Call for applications: CAML Review \\ Appel de mise en candidature : Revue de l'ACBM}

\section{Call for Editor: CAML Review \\ The Canadian Association of Music Libraries, Archives and Documentation Centres seeks a new Editor for its journal, CAML Review.}

CAML Review is the official publication of CAML/ACBM. The journal is published three times a year and includes research articles (peerreviewed section), reports (including official association business), news, essays, and reviews on topics relevant to the purposes of the Association, particularly those pertaining to music in Canada, music librarianship and archival management, and bibliography. Reviews of recordings, books, and reference publications are focused primarily on Canadian content. CAML Review includes materials written in either English or French, the two official languages of the Association. CAML Review is an openaccess publication, licensed under a Creative Commons Attribution-Non Commercial 4.0 International License. The journal can be accessed at https://caml.journals.yorku.ca.

The primary responsibilities of the Editor, in collaboration with the Review Editor and the Associate Editor(s), are as follows: solicit and manage submissions; coordinate the peerreview process; edit, proofread, and format submissions; arrange for translations as necessary; post issues

\section{Appel de mise en candidature, rédacteur en chef : Revue de l'ACBM}

L'Association canadienne des bibliothèques, archives et centres de documentation musicaux est à la recherche d'un nouveau rédacteur en chef pour sa Revue de l'ACBM.

Publication officielle de l'ACBM/la CAML, la Revue de l'ACBM paraît trois fois l'an et comprend des articles de recherche (évalués par les pairs), des rapports (y compris des rapports administratifs), des nouvelles, des essais, ainsi que des comptes rendus traitant de sujets qui correspondent aux objectifs de l'Association, en particulier ce qui concerne la musique au Canada, la bibliothéconomie de la musique, le traitement des archives et la bibliographie. Les comptes rendus d'enregistrements, de livres et d'ouvrages de référence portent surtout sur du contenu canadien. La Revue de l'ACBM est rédigée en français et en anglais, les deux langues officielles de l'Association, et est une publication en libre accès, autorisée par la Creative Commons Attribution - Pas d'utilisation commerciale 4.0 International. On peut accéder à la Revue en se rendant à l'adresse : https://caml.journals.yorku.ca

Travaillant de concert avec le responsable des comptes rendus et le(s) rédacteur(s) adjoint(s), le rédacteur en chef a pour fonctions d'inviter et de gérer les soumissions; de coordonner le processus d'évaluation par les pairs; de réviser, de relire et de formater les soumissions; de demander qu'un texte soit traduit, au besoin; $d$ 'afficher les numéros en ligne (système Open Journal); d'informer les membres de la 
online (Open Journal Systems); disseminate information to members about each newly available issue; and maintain "About the Journal" documentation (e.g. Author Guidelines) on the journal's website. As the journal includes content in both English and French, knowledge of both languages would be an asset.

Applications for the position of Editor should be accompanied by a letter of intent and current curriculum vitae, sent via email to CAML President, Carolyn Doi (carolyn.doi@usask.ca) or Incoming President, Houman Behzadi (houman.behzadi@mcgill.ca). Applications will be accepted until the position is filled. The successful candidate will have the opportunity to receive mentorship from current Editor, Cathy Martin.

\section{กกกกก}

\section{Call for Review Editor: CAML Review}

The Canadian Association of Music Libraries, Archives and Documentation Centres seeks a new Review Editor for its journal, CAML Review.

CAML Review is the official publication of CAML/ACBM. The journal is published three times a year and includes research articles (peerreviewed section), reports (including official association business), news, essays, and reviews on topics relevant to the purposes of the Association, particularly those pertaining to music in Canada, music librarianship and archival management, and parution d'un nouveau numéro et de réunir la documentation paraissant à l'onglet « À propos de la Revue " (p. ex. : les directives aux auteurs) sur le site Web de la Revue. Comme il s'agit d'une revue bilingue, la connaissance des deux langues est un atout.

Les candidatures au poste de rédacteur en chef doivent s'accompagner d'une lettre de motivation et d'un curriculum vitae à jour. Veuillez les faire parvenir par courriel à la présidente actuelle de l'ACBM, Carolyn Doi (carolyn.doi@usask.ca) ou au nouveau président, Houman Behzadi (houman.behzadi@mcgill.ca). Nous accepterons des demandes jusqu'à ce que ce poste soit pourvu. Le candidat choisi aura l'occasion d'être formé par la rédactrice en chef actuelle, Cathy Martin.

\section{กกกกก}

\section{Appel de mise en candidature, responsable des comptes rendus: Revue de l'ACBM}

L'Association canadienne des bibliothèques, archives et centres de documentation musicaux est à la recherche d'un nouveau responsable des comptes rendus pour sa Revue de l'ACBM.

Publication officielle de l'ACBM/la CAML, la Revue de l'ACBM paraît trois fois l'an et comprend des articles de recherche (évalués par les pairs), des rapports (y compris des rapports administratifs), des nouvelles, des essais, ainsi que des comptes rendus traitant de sujets qui correspondent aux objectifs de l'Association, en particulier ce qui concerne la musique au Canada, la bibliothéconomie de la musique, le traitement des archives et la bibliographie. Les comptes rendus d'enregistrements, de livres et d'ouvrages de 
bibliography. Reviews of recordings, books, and reference publications are focused primarily on Canadian content. CAML Review includes materials written in either English or French, the two official languages of the Association. CAML Review is an openaccess publication, licensed under a Creative Commons Attribution-Non Commercial 4.0 International License. The journal can be accessed at https://caml.journals.yorku.ca.

The responsibilities of the Review Editor include identifying publications for review (with priority given to Canadian content), liaising with review authors, and editing submissions. Questions or applications for the position of Review Editor should be accompanied by a letter of intent and current curriculum vitae, sent via email to CAML President, Carolyn Doi (carolyn.doi@usask.ca) or Incoming President, Houman Behzadi (houman.behzadi@mcgill.ca). Applications will be accepted until the position is filled. référence portent surtout sur du contenu canadien. La Revue de l'ACBM est rédigée en français et en anglais, les deux langues officielles de l'Association, et est une publication en libre accès, autorisée par la Creative Commons Attribution - Pas d'utilisation commerciale 4.0 International. On peut accéder à la Revue en se rendant à l'adresse : https://caml.journals.yorku.ca.

Les fonctions du responsable des comptes rendus incluent les suivantes : choisir les publications à commenter (en accordant la priorité au contenu canadien), travailler en liaison avec les auteurs de comptes rendus et réviser les soumissions. Les candidatures à ce poste doivent s'accompagner d'une lettre de motivation et d'un curriculum vitae à jour. Veuillez les faire parvenir par courriel, ainsi que toute question, à la présidente actuelle de l'ACBM, Carolyn Doi (carolyn.doi@usask.ca) ou au nouveau président, Houman Behzadi (houman.behzadi@mcgill.ca). Nous accepterons des demandes jusqu'à ce que ce poste soit pourvu. 


\title{
The Consummate Value of (Manitoba Chamber Orchestra's) Classical Music Recordings
}

\author{
by Conrad Sweatman
}

Anyone outside the Top 40 world who records CDs in this day and age might be accused of artistic vanity. Consider this 2015 headline from impish classical blogger Norman Lebrecht on Slipped Disc: "Adele's album sold 3.4M last week. The classical \#1 sold 493." The classical artist in question was Yo Yo Ma.

No shade on Adele, but for those of us who like coffee with our sugar, a bit of Beethoven alongside The Beatles, let's not pretend this trend isn't at least a little discouraging. But how much so? So much that it should stop Yo Yo Ma, or even those talented musicians among us who don't chart in the Top 10, from gracing the world with a durable document of the miracles we conduct on stage?

Phrased that way, the question implies a clear answer in the negative. I'm biased, as a dedicated marketer of classical music, so I'll relate a persuasive argument on this matter made by a non-musician friend of mine. Challenged to defend the social value of concert music in utilitarian terms, she argued that such value lay in concert music's prominent place in the public domain. In a sense, we all have a stake in the preservation of classical music, just as we all have a stake in the preservations of the commons.

I might extend her argument to point out that most Canadian classical music organizations are non-profits, whose budgets are supported indirectly by democratic mandate, and who generally, in my experience, do their utmost to keep their concerts and recordings affordable for Jane Q. Citizen.

Take MCO Records, which I help to promote in my capacity as Manitoba Chamber Orchestra's Marketing and Communications Manager. We're about to release Cello Concerto, an EP featuring the excellent music of Canadian composer Michael Oesterle and a performance by the MCO and Canadian cellist Ariel Barnes. We've priced the CD at a mere $\$ 12$. The current

Conrad Sweatman (csweatman@themco.ca) is Marketing and Communications Manager for the Manitoba Chamber Orchestra.

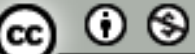

This work is licensed under a Creative Commons Attribution-NonCommercial 4.0 International License. 

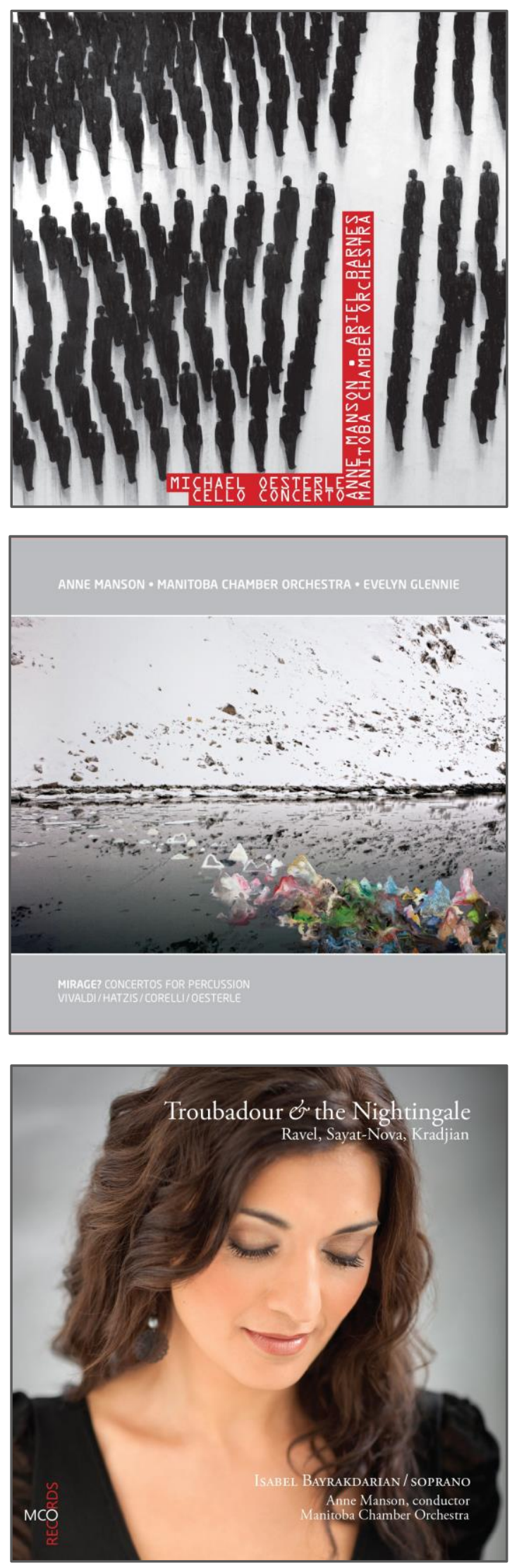

retail price of our 2017 release of Mirage? Concertos for Percussion-which features Dame Evelyn Glennie and includes the music of Canadian composer Christos Hatzis, Vivaldi, and others-is $\$ 10$. Same goes for our JUNO-nominated album, Troubadour and the Nightingale, with CanadianArmenian soprano Isabel Bayrakdarian. Our concert ticket prices are also affordable, which probably explains why our concerts remain so popular with a diverse group of Manitobans and Canadians. And for those who can't make it to MCO's core concerts, there are free MCO workshops and satellite concerts across the province and free streamable concerts online.

Avid concert music fans will feel less pressure to justify the recording and production of concert music in utilitarian terms. They will purchase and recommend albums such as those just mentioned purely for their own sake, with little thought about the greater good. But in our world of ones and zeroes, pragmatism and penny-pinching politicians, there are many other ways to justify such expenditures. Here's one relevant to the MCO Records: our albums are a who's who of top Canadian soloists, orchestral players, and composers. In this sense, they provide the Canadian student of music with a useful virtual introduction to the world of Canadian professional music, as well as some very strong and instructive performances of the common practice tradition.

Contact me at csweatman@themco.ca or visit our website themco.ca for more information about MCO Records' titles. 


\title{
Sounds of Home: A Survey of Local Music Collection Management Practices in Canadian Libraries
}

\author{
by Carolyn Doi and Sean Luyk
}

\section{Abstract}

This paper describes the findings of a national survey of local music collection managers in Canadian libraries in 2018. The survey aims to capture a snapshot of local music collection management practices by identifying areas where collection managers make use of specialized skills and competencies and where practices may be improved. An online questionnaire was sent to local music collection managers in Canadian libraries and consisted of 20 questions that addressed demographics, collection scope, collection development, promotion, access, and preservation.

The results show that local music collections are diverse in scope and include a wide range of formats. Many include archival materials or are described or organized using archival principles. Collection managers use a range of strategies to build and develop local music collections, including working with community members and donors to identify, select, and purchase collection materials. Collections are used most frequently by community members and researchers to conduct scholarly or historical research. Outreach and promotion are areas where collection managers are using diverse strategies, including community engagement, event hosting, and online marketing, to build awareness of collections. Physical and digital preservation practices are being implemented by most participants, and online access to collections is often available through additional collection description or digitization.

Collection managers may face challenges due to the unique nature of local music collections. Strategies for collection management, collection development, outreach, or promotion may fall outside traditional professional skill sets or competencies. Areas for development include donor relations, community engagement, and archival collection management.

Carolyn Doi (carolyn.doi@usask.ca) is the Music \& Education Liaison Librarian at the University Library, University of Saskatchewan. Sean Luyk (sean.luyk@ualberta.ca) is Discovery \& Web Services Librarian at the University of Alberta Libraries.

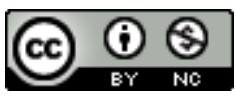

This work is licensed under a Creative Commons Attribution-NonCommercial 4.0 International License. 


\section{Introduction}

The idea of the "connectedness of music" - to specific places and spaces-is a compelling one. Many forms of cultural production, such as books, films, television, and news media, have capitalized on the associations between musical genres and geographic locations. Although these associations do not accurately depict the multitude of local musical cultures active in a location at a given time and fail to represent the realities of how musical cultures operate within the shifting boundaries between the local, national, and global, the association they make between music and place is powerful. Local music, and by extension local music collections, are rich sources of information that can inform bigger questions that build on this idea of connection and the interplay between the local, national, and global in music. Those who develop and maintain local music collections in cultural heritage institutions have a similarly important part to play in answering these questions. By examining their collection management practices, we can begin to better understand the nature of local music materials, the role that local music collections play in preserving historical narratives, and the interplay between the local music community (musicians, fans, collection users, donors, etc.) and the institution.

This paper describes the results of a survey of Canadian local music collectors in Canadian libraries administered in May 2018 as part of the SSHRC supported project: Sounds of Home: Exploring Local Music Collections and Collecting Practices in Canada (hereafter referred to as Sounds of Home). The purpose of the Sounds of Home project is 1 ) to identify where collections of local music are held, what music(s) they document, and what evidentiary value they possess; and 2) to understand the perceived value of collecting local music, and to record local music collection management practices currently used by public institutions to determine areas where practices may be improved. The survey described in this paper represents the first phase of Sounds of Home, the purpose of which was to increase our understanding of the locations of local music collections in Canadian libraries, to document the practical strategies collectors use, and to document the challenges they face with regard to this work. Within Sounds of Home more broadly, music collections are defined as "local" when they demonstrate a connection - through a person, organization, or topic - to a delimited geographic region. The survey data informs us of the current professional practices of local music collectors, provides some possible areas for improving collecting practices, and suggests ideas for future research on the topic of local music collecting. The research addresses a significant gap in the professional and scholarly literature on the topic of local music collecting in libraries and, for the first time, reports on the impressions and practices of local music collection managers in libraries in an aggregate format.

\section{Background}

One of the major motivating factors for this research is the theory that local music collections form the basis of broader understandings of music and its relationship to national and global identities. The work and perspectives of local music collection managers play an essential role in understanding this relationship. This is especially important in the Canadian context because 
Canadian music is already an underrepresented area of study, and Canadian local music is arguably even more so. In his examination of the history of music in Edmonton, Alberta, Gramit notes that studies of local music have historically been situated at the margins of musicological research, and within the field of American music studies, the few studies on local music cultures that do appear tend to be about major metropolitan areas. ${ }^{1}$ Having the source materials available to study local music histories that are at the margins is, therefore, one important act in addressing this gap. Enhanced understandings of the role of local music collections as contributors to identity will be of great value across a wide range of cultural, media, and historical studies.

Frameworks supporting this research include music studies, and library and archival sciences perspectives. With regard to the musicological perspective, this work is grounded in the "scenes approach," which argues that local music scenes are part of broader cultural formations that may act as texts in the construction of evolving and contested identities. In this approach, local music is considered as both locally significant and also connected to the wider world. As Bennett writes, local music illustrates "the importance of locality, and local structures of feeling, in revealing the significance of musical life - and the connectedness of music to other aspects of local history, heritage and culture." 2

Straw is credited with first introducing the scenes approach through a scholarly lens, diverging from previous work that drew upon discussions of genre based on typically commercial constructs. ${ }^{3}$ Scholarship on music scenes has since focused primarily on independent popular music scenes that operate outside of conventional means of distribution. This scholarship has employed wide-ranging methodologies, including cultural studies, the sociology of music, and popular music studies. ${ }^{4}$ The concept of the music scene provides us with a useful theoretical framework to draw upon when considering the practice of local music collecting, given the importance it places on ideas of space and place as they inform understandings of cultural production, including music. Related research in

1. David Gramit, "The Transnational History of Settler Colonialism and the Music of the Urban West: Resituating a Local Music History," American Music 32, no. 3 (2014): 272-73, https://doi.org/10.5406/americanmusic.32.3.0272.

2. Andy Bennett, "Popular Music and the 'Problem' of Heritage," in Sites of Popular Music Heritage: Memories, Histories, Places, Routledge Studies in Popular Music 4 (New York: Routledge, 2015), 24.

3. Will Straw, "Systems of Articulation, Logics of Change: Communities and Scenes in Popular Music," Cultural Studies 5, no. 3 (1991): 368-88.

4. Core research on music scenes includes: Richard A. Peterson and Andy Bennett, Music Scenes : Local, Translocal \& Virtual (Nashville, TN: Vanderbilt University Press, 2004); Andy Bennett, "Consolidating the Music Scenes Perspective," Poetics: Journal of Empirical Research on Culture, the Media and the Arts 32, no. 3-4 (2004): 223-34; Holly Kruse, Site and Sound: Understanding Independent Music Scenes, Music/Meanings, vol. 1 (New York, NY: P. Lang, 2003); John Connell and Chris Gibson, Sound Tracks : Popular Music, Identity, and Place, Critical Geographies 17 (London: Routledge, 2003). 
ethnomusicology, that has also sought to unpack definitions of local music and its relationships to national or global musics, is further instructive in this research. ${ }^{5}$

When considering local music collecting and the library, we draw on the disciplines of special collections librarianship and particularly local heritage collecting. As Dixon writes, "local studies collections are almost as old as libraries themselves." ${ }^{16}$ Preservation, stewardship, access, and management of historical collections and original artifacts serve as cornerstones of the professional knowledge in this discipline. ${ }^{7}$ Dewe, writing about the value of local history materials in libraries, argues that these collections make a contribution "...toward an understanding and interpretation of regional and national history... [and] as having social values for individuals and groups... [this] shared sense of local history, and an involvement with it, can also be seen as a way of strengthening communities and helping move towards the goal of social inclusion." 8 While the benefit of local heritage collections in libraries is clear, Dewe goes on to advocate for better training and subject knowledge for library staff who serve the local community and build local collections to "meet the needs of demanding users who look for a depth of subject knowledge."

There are parallels between the challenges and professional needs of local heritage collecting and local music collecting. Berger's work in this area is especially relevant as he discusses practical questions of how local music collections may best be preserved and presented. ${ }^{9}$ Early in the history of music librarianship as a profession, Spivacke argued that local music collecting impacts both local communities and the nation by providing more "complete" musical histories. ${ }^{10}$ Epstein made similar arguments, suggesting that through the activity of collecting and compiling local music collections, libraries can help connect local musical pasts to national cultural and social developments. ${ }^{11}$ She would prove these claims to be true nearly a decade later, through her significant contributions to the study of African-American musical culture, drawing extensively on the use of local music

5. Significant ethnomusicological works include: Jocelyne Guilbault, "On Redefining the Local through World Music," in Ethnomusicology: A Contemporary Reader (New York: Routledge, 2006), 137-46; Jan Fairley, "The 'Local' and 'Global' in Popular Music," Cambridge Companions to Music (New York, NY: Cambridge University Press, 2001), 272-89; Ian D. Biddle and Vanessa Knights, Music, National Identity and the Politics of Location : Between the Global and the Local, Ashgate Popular and Folk Music Series (Burlington, VT: Ashgate, 2007).

6. Diana Dixon, "From Manuscripts to Metadata: The Changing Face of Local Studies Librarianship," APLIS 24, no. 2 (June 2011): 74.

7. American Library Association, "Guidelines: Competencies for Special Collections Professionals," July 8, 2008, http://www.ala.org/acrl/standards/comp4specollect.

8. Michael Dewe, "Local Studies and Libraries," in Local Studies Collection Management (London: Routledge, 2016), 4.

9. Sidney E. Berger, "What Is So Rare...: Issues in Rare Book Librarianship," Library Trends 36, no. 1 (1987), http://hdl.handle.net/2142/7513.

10. Harold Spivacke, "Collection of Musical Material of Local Interest," Music Library Association Notes, no. 8 (August 3, 1940): 49-54.

11. Dena J. Epstein, “On Collecting Materials for Local Music Histories," Notes: Quarterly Journal of the Music Library Association 24, no. 1 (1967): 18-21, https://doi.org/10.2307/894777. 
sources. ${ }^{12}$ More recent publications in music librarianship on local music collections include case studies that describe individual collections; ${ }^{13}$ articles that advocate for the importance of collecting local music; ${ }^{14}$ discussions of practical challenges related to the collection, storage, and accessibility of local music artifacts; ${ }^{15}$ and examinations of local music collections in the media. ${ }^{16}$ More broadly, a growing body of literature about cultural heritage institutions and local music also informs this research, including literature on local music in museums and archives, the evolving role of community archives, ${ }^{17}$ and work concerning the role of amateurs in collecting and documenting popular music material culture. ${ }^{18}$

\section{Method}

Both the professional and theoretical background presented here informed the survey design and research questions. When constructing the survey, we followed Bhattacherjee's methodology for online questionnaire surveys. ${ }^{19}$ The online questionnaire was created in English (see Appendix 1:

12. Dena Epstein, Sinful Tunes and Spirituals: Black Folk Music to the Civil War (Urbana: University of Illinois Press, 2003).

13. Robert Murrell Stevenson, "Local Music History Research in Los Angeles Area Libraries," Inter-American Music Review 10, no. 1 (1988): 19-38; Edward W. Hathaway, "Developing a State Archive of Local Music Materials," Notes: Quarterly Journal of the Music Library Association 45, no. 3 (1989): 483-94; Lara Allen, "Preserving a Nation's Heritage: The Gallo Music Archive and South African Popular Music," Fontes Artis Musicae, no. 3 (2007): 263; Jeff Wanser, "Collecting and Collaborating to Build Community: The Evolution of a Local Music Collection at a Small Liberal Arts College Library," Technical Services Quarterly 31, no. 4 (October 2, 2014): 332-57, https://doi.org/10.1080/07317131.2014.908586; Priscilla Winling, "Bringing the Local Music Scene to the Public Libraries Network of Strasbourg: A Live Collection," Fontes Artis Musicae 59, no. 2 (2012): 127-33, http://www.jstor.org/stable/42765570.

14. Sean Luyk, "Scene but Not Heard: Collecting Local Music," CAML Review / Revue de l'ACBM 41, no. 1 (2013): 22-33; John Vallier, "Sound Archiving Close to Home: Why Community Partnerships Matter," Notes: Quarterly Journal of the Music Library Association 67, no. 1 (2010): 39-49.

15. Michael Rafferty, "Compiling a Comprehensive Local Music Archive - Some Problems," Local Studies Librarian 20, no. 2 (2001): 12-13; Richard Belford, "Building a Regional Music Collection: The Saskatchewan Experience," CAML Review / Revue de l'ACBM 35, no. 1 (2007): 19-22; Carolyn Doi, "Local Music Collections in Cultural Heritage Institutions: A Qualitative Systematic Review," Fontes Artis Musicae 65, no. 4 (2018); Carolyn Doi, "Local Music Collections: Strategies for Digital Access, Presentation, and Preservation-A Case Study," New Review of Academic Librarianship 21, no. 2 (2015): 256-63, https://doi.org/10.1080/13614533.2015.1022663.

16. Veronica Kmiech, "In Other News: The Significance of Canadian Media Sources in an Analysis of Local Music Collection Literature," CAML Review / Revue de l'ACBM 46, no. 1 (2018): 6-16.

17. Sarah Baker and Jez Collins, "Sustaining Popular Music's Material Culture in Community Archives and Museums," International Journal of Heritage Studies 21, no. 10 (2015): 983-96, https://doi.org/10.1080/13527258.2015.1041414; Sarah Baker, Peter Doyle, and Shane Homan, "Historical Records, National Constructions: The Contemporary Popular Music Archive," in Popular Music and Society, vol. 39 (Abingdon, Oxfordshire, United Kingdom: Routledge, 2016), 8-27; Marion Leonard, “Constructing Histories through Material Culture: Popular Music, Museums and Collecting," Popular Music History 2, no. 2 (2007): 147-67, https://doi.org/10.1558/pomh.v2i2.147.

18. Sarah Baker, ed., Preserving Popular Music Heritage: Do-lt-Yourself, Do-It-Together, Routledge Research in Music 11 (New York: Routledge, 2015).

19. Anol Bhattacherjee, Social Science Research: Principles, Methods, and Practices, Textbooks Collection 3 (Global Text Project, 2012), https://scholarcommons.usf.edu/oa textbooks/3/. 
Questionnaire, English) and translated to French (see Appendix 2: Questionnaire, French). The study received an ethics exemption from the University of Saskatchewan on November 8, 2017, and ethics approval at the University of Alberta on November 29, 2017. The survey was coded using Voxco survey software and administered by the Social Sciences Research Lab at the University of Saskatchewan. A link to the survey and invitation to participate were distributed by email to potential participants on May 3, 2018. Two reminders were sent prior to the survey closing on May 22, 2018. Local music collectors working in Canadian libraries were invited to participate. These included public library contacts in major Canadian cities, music librarians and special collections librarians from academic institutions, music conservatory librarians, and music librarians at national libraries and music research centres. Additional potential participants were identified by sending the survey to public libraries in major cities, academic music libraries, and other likely institutions. We made our selection from directories for professional associations and organizations (e.g., Canadian National Digital Heritage Index, Canadian Association of Music Libraries) and publicly available online information from provincial post-secondary institution directories. Potential survey participants were required to answer a qualifying question that asked if they managed a local music collection where the scope was a delimited geographic area (e.g. town, city, neighborhood, province, territory, region, etc.) in order to be included in the study.

The survey consisted of 20 questions: 16 closed questions (yes/no, multiple choice, and ranking), and four open-ended. Questions were divided into six categories: demographics, collection scope, collection development, promotion, access, and preservation. The survey preamble provided a definition of local music collections and participants were excluded from the survey if they did not identify as a manager of a local music collection at a Canadian library.

\section{Results}

Of the 105 potential participants identified, 49 (46.66\%) opened the survey link in the recruitment email. Twenty-four participants did not complete the survey and 12 did not meet eligibility screening and were excluded from the survey. Thirteen participants completed the survey and were included in this study. ${ }^{20}$ The majority $(8,61.5 \%)$ of the participants are located in Western Canada, followed by three (23.1\%) from Central Canada, and two (15.4\%) from Eastern Canada. The majority of participants work at academic institutions $(8,61.5 \%)$, followed by public libraries $(3,23.1 \%)$ and special libraries $(2,15.4 \%)$. See table 1 for a more detailed breakdown of geographic and institutional representation.

20. Carolyn Doi and Sean Luyk, “Local Music Collections and Collecting in Canada," September 18, 2018, https://doi.org/10.7939/DVN/WAJ9UG. 
Table 1: Participants

\begin{tabular}{|c|c|c|c|c|c|c|}
\hline Region & Province & Academic & Public & Special & $\begin{array}{l}\text { Frequency } \\
\text { total }\end{array}$ & Percentage \\
\hline \multirow[t]{4}{*}{$\begin{array}{l}\text { Western } \\
\text { Canada }\end{array}$} & $\begin{array}{l}\text { British } \\
\text { Columbia }\end{array}$ & 2 & 0 & 0 & 2 & $15.38 \%$ \\
\hline & Alberta & 1 & 1 & 1 & 3 & $23.08 \%$ \\
\hline & Saskatchewan & 1 & 0 & 0 & 1 & $7.69 \%$ \\
\hline & Manitoba & 1 & 0 & 1 & 2 & $15.38 \%$ \\
\hline Central Canada & Ontario & 1 & 2 & 0 & 3 & $23.08 \%$ \\
\hline \multirow[t]{2}{*}{ Eastern Canada } & Newfoundland & 2 & 0 & 0 & 2 & $15.38 \%$ \\
\hline & Total & 8 & 3 & 2 & 13 & $100.00 \%$ \\
\hline
\end{tabular}

\section{Collection descriptions}

We asked participants to describe their local music collections, including growth, scope, and formats. Almost all participants $(12,92.31 \%)$ indicated that their collections are currently growing (Q11). When describing the scope of their collections, participants used a variety of definitions of "local music" to limit the scope. In some cases, the scope statements described limitations based on the institution, city, or province:

"[The collection is] mostly focused on music created and performed at [the institution]."

"Our database ... aims to identify all NL recordings, even those we don't own."

"The 'local music' collection at the [Institution] mainly focuses on Manitoba composers, faculty performers, and publications of graduates and faculty of our program."

Participants also attempted to define the collection by additional limits. It was quite common to see references to format and material types that may be included:

"We collect: commercial recordings by Newfoundlanders and Labradorians (resident or nonresident) and commercial recordings produced in Newfoundland and Labrador (including those by non-Newfoundlanders); commercial DVDs of musical performances; monographs concerning NL music; song-books and guides to teaching instruments."

"...mostly collections housed in archives and special collections." 
"Our scope is to obtain popular local music on CD and through our streaming platforms Freegal and Hoopla."

Scope statements also made references to the types of artists or music included in the collection, or the types of topical content that are collected:

"To collect music recorded in Saskatchewan, sheet music by Saskatchewan composers and both recorded and music composed by musicians (including singers, songwriters, bands, indigenous groups and classical musicians - either originally from Saskatchewan or living there now)"

"We have Biography files containing newspaper clippings about musicians/performers. We also have a database (Periodical Article Bibliography) that would help identify magazine and journal articles about NL music."

Participants were asked to indicate which formats were included in the local music collections (fig. 1). All participants (100\%) indicated that sound recordings are included, followed by video recordings (69.23\%), notated music (61.54\%), and concert programs (61.54\%). Participants who selected the response "other" included formats such as "personal and professional correspondence, and other textual records included in archival fonds" and "archival records" in their responses.

\section{Figure 1: Collection formats}

Q5 What formats are included in the local music collections?

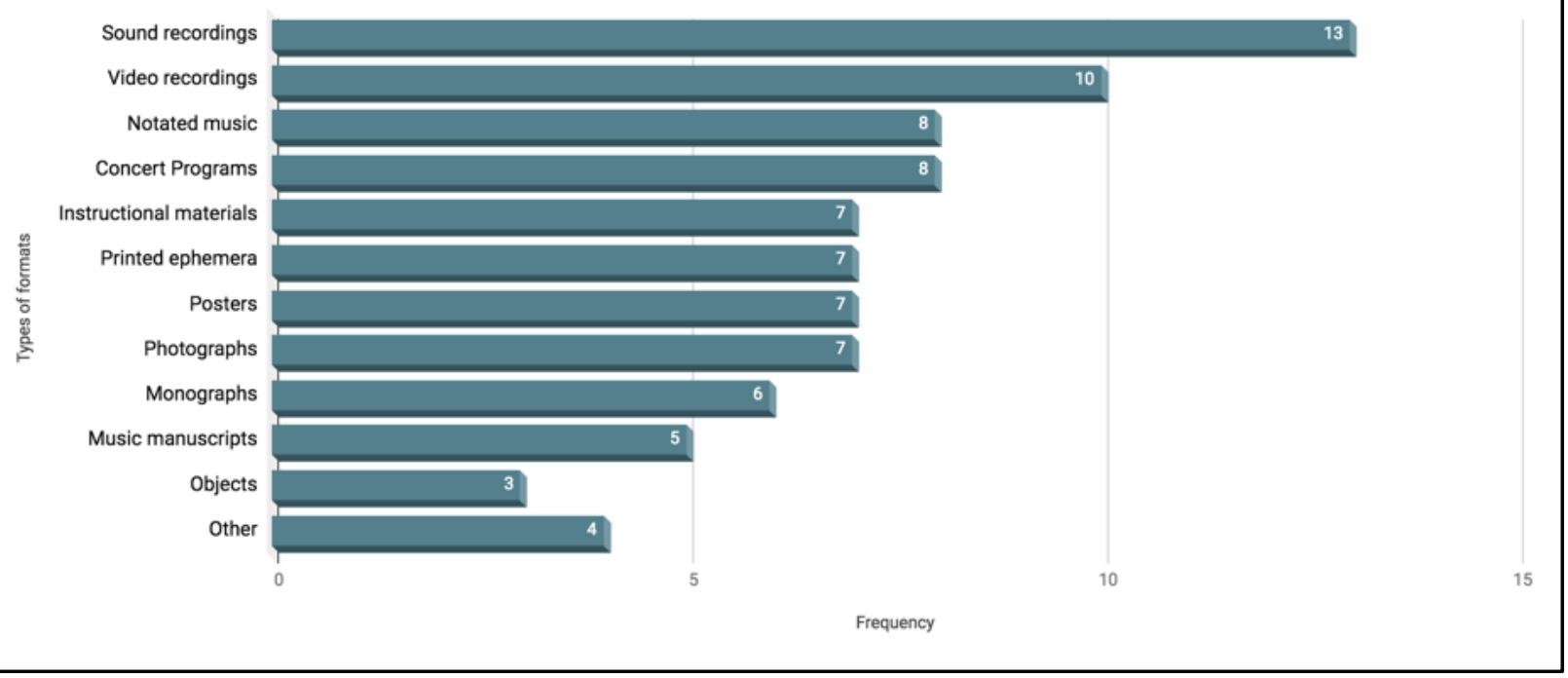




\section{Access and preservation}

We asked participants where and how they provide access to the local music collections and how they are preserved. When asked how users are currently able to access the collections (Q6), all participants (100\%) responded that collections are accessible in person. Of those, eight (61.53\%) responded that the collections are also available online. Two participants clarified their responses in the open-ended portion of the question to indicate that their collections came with limitations on access. One participant indicated, "much of our backlog material is only accessible with the donor's written permission." Another participant said: "Vimeo [is used] for some recordings [but this is] very limited."

In response to the question asking where local music collection materials are located, most participants $(8,61.54 \%)$ indicated that materials are located in an archive or special collections unit (fig. 2). Other locations included interfiling with other music collections $(6,46.15 \%)$, storage (5, $38.46 \%)$, a special collection within a music library $(4,30.77 \%)$, and within another local history collection ("other," 1, 7.69\%). Participants were able to select more than one location where collection materials were held, which accounts for the greater number of responses than the total number of participants.

\section{Figure 2: Physical location of local music collections}

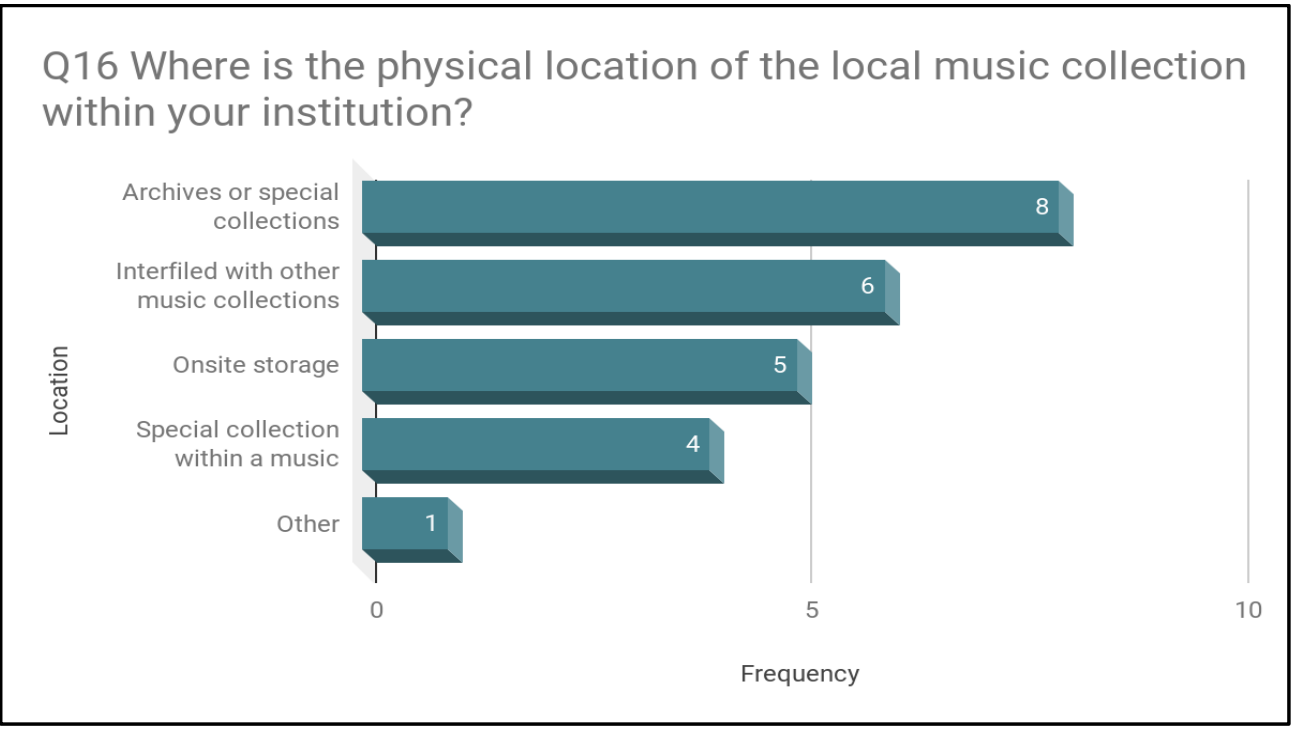

When asked if the local music collections have been catalogued, participants responded that cataloguing of some kind has been done. Nine participants $(69.23 \%)$ responded that the collection had been fully catalogued while four (30.77\%) responded that the collection has been partially catalogued. Based on these responses, we asked participants whether they have used any metadata in catalogue records to indicate that collection materials are part of a local music collection. In response, the majority $(9,69.23 \%)$ answered that metadata has been applied, while a few answered that additional metadata has not been applied $(3,23.08 \%)$, and one participant indicated 
that it is sometimes applied (7.69\%). If participants indicated that metadata is applied (with all or some materials), then they were asked how metadata is used to indicate that materials are part of a local music collection. Of the 10 participants who indicated that metadata is used to identify items held in a local music collection, four use an added series note or added subject headings. Four participants selected the "other" option, which included metadata strategies such as adding a local note, ISAD(G) metadata, ${ }^{21}$ archival description, and using a separate collection location.

Table 2: Use of metadata to indicate inclusion in a local music collection

\begin{tabular}{|l|lll|}
\hline \multicolumn{2}{|c}{ Frequency } & Percentage & Cumulative percentage \\
\hline Added series note & 4 & $28.57 \%$ & $28.57 \%$ \\
Added subject headings & 4 & $28.57 \%$ & $57.14 \%$ \\
Added name field & 2 & $14.29 \%$ & $71.43 \%$ \\
Other & 4 & $28.57 \%$ & $100.00 \%$ \\
Total & 14 & $100.00 \%$ & \\
\hline
\end{tabular}

When asked what steps have been taken to preserve the collection materials (Q17), the majority of participants reported that they are implementing digital preservation strategies $(9,47.37 \%)$, while others noted that they are implementing physical preservation strategies $(6,31.58 \%)$. Participants were able to select both digital and physical preservation as options in this question. When asked to respond to the question "what steps have been taken to physically preserve collection materials" (Q18), participants responded with a variety of strategies. Several mentioned the use of archival preservation practices:

"...archival arrangement and description, environmental controls in storage facility, enforcing proper handling techniques in the reference room."

"...acid-free file folders in acid-free boxes."

In regard to the supervised access and use of local music collection materials, responses included:

"[materials] must be used within the library. They don't leave the library. Quality playback equipment has been provided to limit wear and tear on original materials. Specialized (custom) media storage/browsing cabinets have been constructed."

21. The General International Standard Archival Description (ISAD(G)) is used to "identify and explain the context and content of archival material in order to promote its accessibility." International Council on Archives, https://www.ica.org/sites/default/files/CBPS 2000 Guidelines ISAD\%28G\%29 Second-edition EN.pdf. 
"Advocacy for a specialized vault. Our on-site Preservation Officer provides services for damaged, or at-risk items."

When asked to respond to the question "what steps have been taken to digitally preserve collection materials" (Q19), participants responded primarily with examples of digitization as a means of preserving collection materials. Several participants emphasized the need to digitize materials that are in unstable formats:

"Digitizing in preservation formats that have backwards and forwards compatibility; triaging so that the most unstable formats are digitized and preserved first"

"Obsolete media have been migrated to digital formats."

"Digitization of at-risk media is ongoing. DVDs are backed up into various formats that are stored on a secure server. The Library is currently testing digital management programs for the long-term preservation and access."

Other participants mentioned digitization of specific formats or specific projects:

"Digitization of audio recordings"

"Beginning to digitize and create an online database of recital works."

"There is also an on-going program that is digitizing the collection or at least part of the collection, which will then become digital assets that will become part of the digital preservation strategy."

\section{Use of local music collections}

We asked participants to identify the users of their local music collections and to describe the ways the collections are used. In Q8, participants were asked to identify the users who access the local music collections and to rank these users by the frequency of use. The most frequent users are community members who were identified as users in 11 cases, and of these, eight $(72.72 \%)$ were identified as primary or secondary users of the collection. Researchers were also identified as frequent users of local music collections in 11 cases, and of these, seven (63.63\%) are identified as primary or secondary users. Other user groups that used the collections less frequently included students, visitors from other communities, and donors (fig. 3). 
Figure 3: Users of local music collections

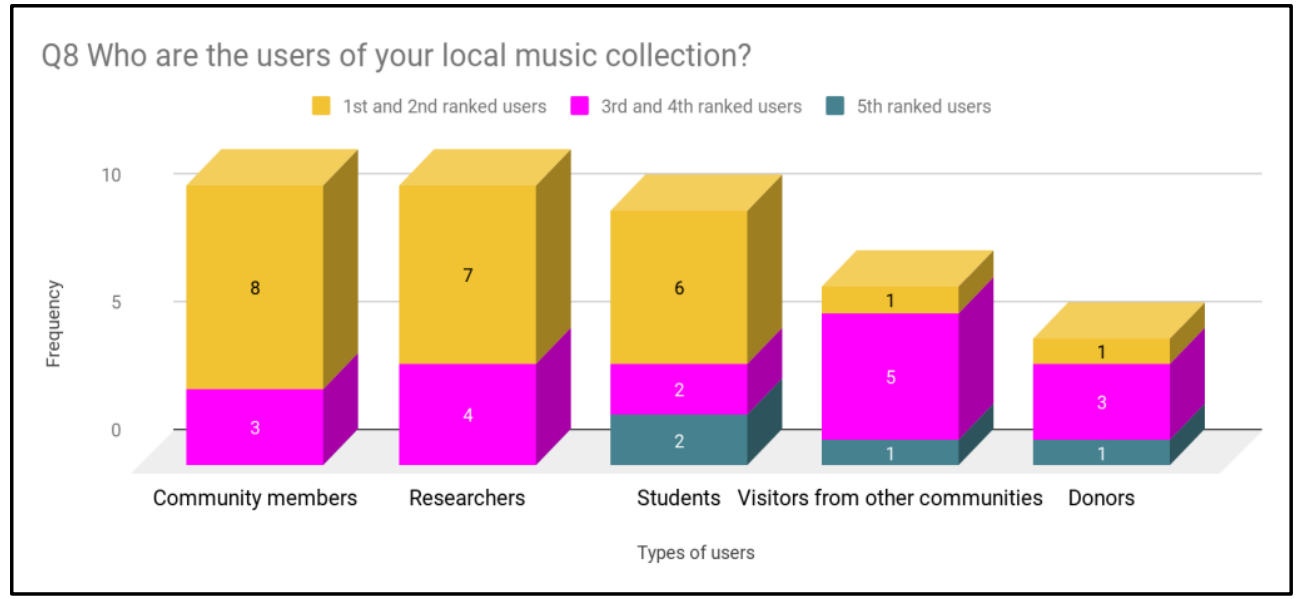

In response to the question "how do users make use of your local music collections?" (Q9) the highest ranked uses are scholarly research (7, 53.85\%) and historical research (6, 46.15\%). Subsequent uses include teaching, community research, artistic work, and family research. One participant indicated that they do not know how the collection is used (fig. 4). Open-ended responses for this question indicate more specific examples of collection use:

"[to] learn about local artists, entertainment"

"for use in musical performance or study"

"[in] creative projects: remounts of shows, re-staging of shows/pieces, creation of new creative works (plays, dance, music)"

"Heritage Fairs at schools"

"[to allow] music collectors [to] check their lists against our holdings"

\section{Figure 4: How local music collections are used}

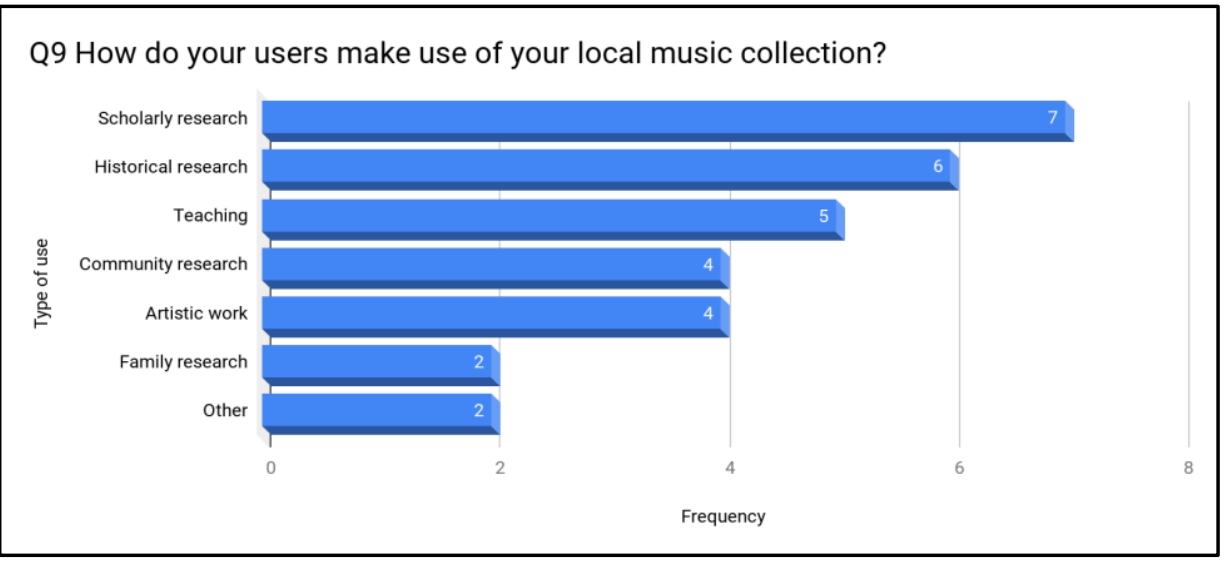




\section{Acquisitions}

We asked the participants about the acquisitions process, including where and how they identify, select, and obtain materials for the collections (Q11, Q13, and Q15). When asked to rank the usefulness of tools or strategies for identifying and selecting collection materials, most participants identified conducting research on local music as either useful or very useful (11, 84.61\%). Gathering collecting suggestions through community engagement events and establishing or updating a collection development policy were also identified as useful or very useful strategies $(7,53.84 \%)$. Other options are also used but considered less useful, such as building community partnerships, selecting from offerings at music stores/vendors, building lists, and getting suggestions through media sources (fig. 5).

Figure 5: Tools and strategies for identifying and selecting collection materials

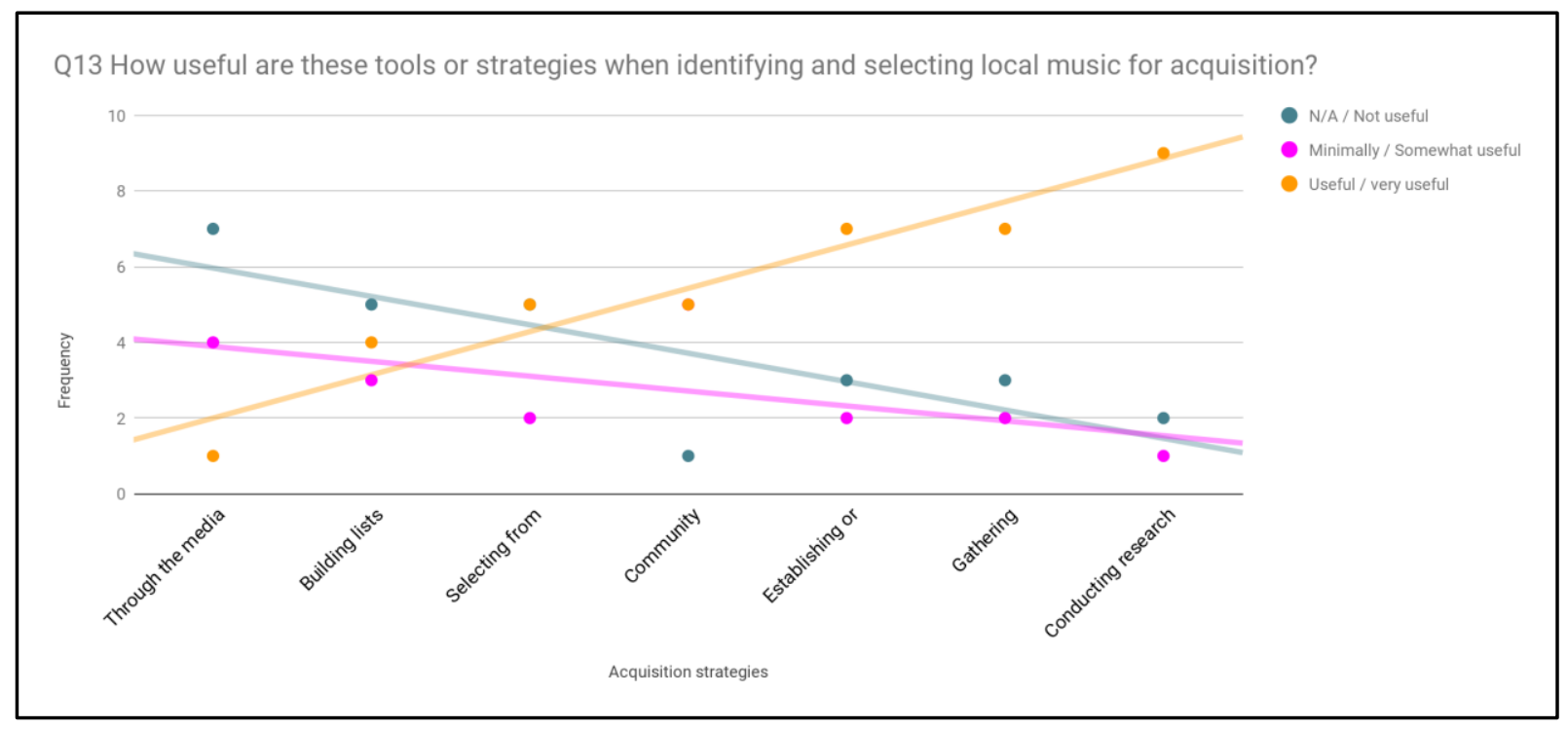

When asked how often certain sources were used when acquiring local music materials, "music stores and vendors" was identified by the most participants as a source they used frequently or very frequently $(6,46.15 \%)$. This was followed closely by acquiring materials through donations and from individual artists and bands (5,38.46\%). Other methods included acquisitions by way of community organizations, music labels and publishers, self-produced sound recordings, purchases at events, and through social media (fig. 6). 
Figure 6: Local music acquisition sources

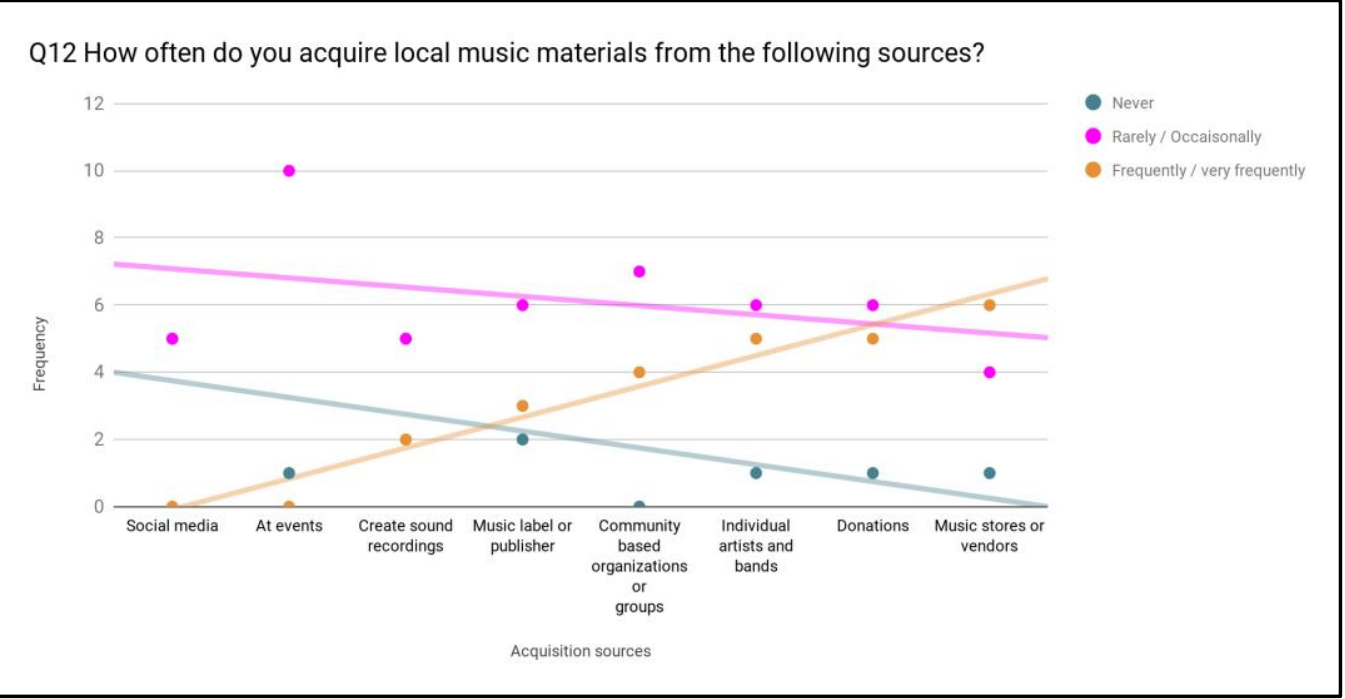

Participants were asked to identify and rank acquisition strategies for collecting local music materials. Establishing donor agreements and licensing agreements were ranked as the most important strategies. Of those who selected donor agreements as an acquisition strategy (10, $76.92 \%)$, three participants identified this as their primary or secondary strategy. Of those who selected licensing agreements as an acquisition strategy, five identified this as either a primary or secondary strategy. Other strategies include maintaining flexibility, advocacy, hosting events to collect local music materials, and implementing a promotional activity or strategy (fig. 7). One participant selected the "other" option, and included a variety of strategies in their response:

"working with our vendor to help us with our awareness of local works; Speaking with musicians and those who work in recording studios and keeping up-to-date with what's happening on [websites] and reading Arts \& Entertainment guides..."

Figure 7: Strategies for acquiring local music materials

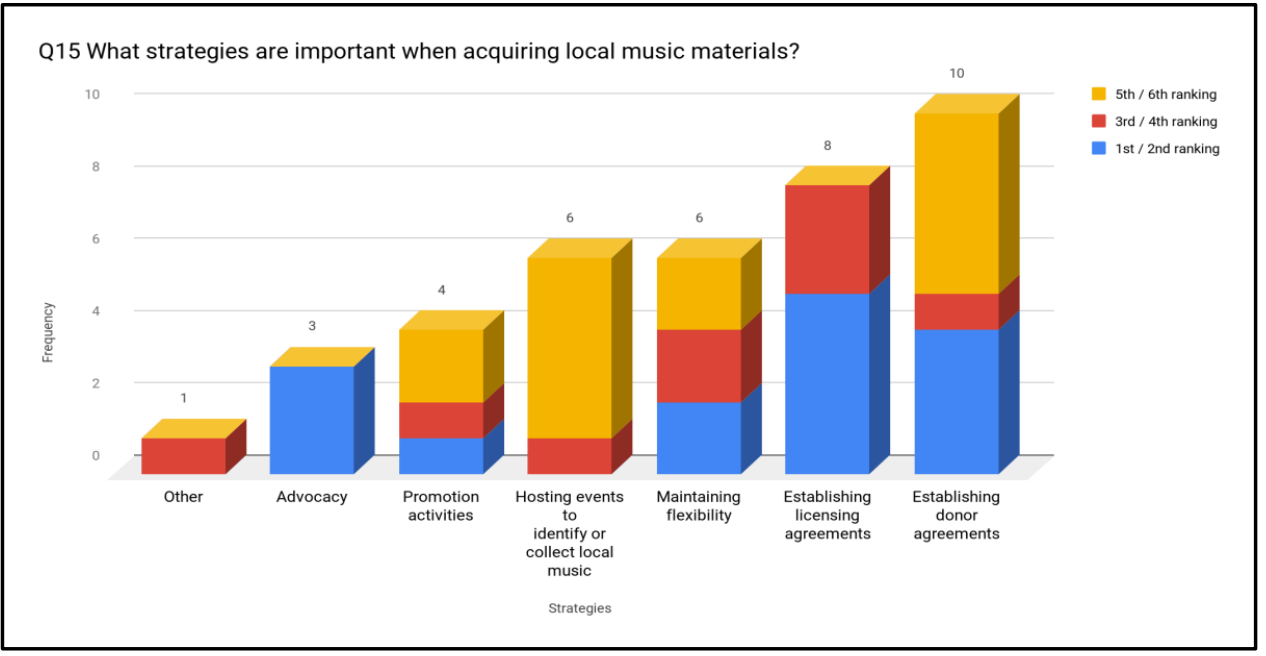




\section{Promotion, outreach, and funding}

We asked participants about how they manage promotion and outreach for their local music collection. When asked how funds for local music collection materials are secured (Q14), participants indicated that most often, funding comes from an institutional collections fund ( 9 , $33.33 \%)$ or through donations from the wider community $(8,29.63 \%)$. Other funding sources include endowment funds, grants, and government funding (see table 3 ). Many participants selected more than one funding source, suggesting that funding sources are varied and that one source may not be sufficient on its own.

Table 3: Funding sources for local music collections

\begin{tabular}{|l|ll|}
\hline \multicolumn{1}{|l}{} & Frequency & Percentage \\
\hline Main institutional collection fund & 9 & $33.33 \%$ \\
$\begin{array}{l}\text { Donations from members of the } \\
\text { community }\end{array}$ & 8 & $29.63 \%$ \\
Designated endowment funds & 5 & $18.52 \%$ \\
Grants & 3 & $11.11 \%$ \\
Government funding & 2 & $7.41 \%$ \\
Total & $\mathbf{2 7}$ & $100.00 \%$ \\
\hline
\end{tabular}

In response to the question "how are local music collection(s) promoted?" collection managers indicated a wide range of strategies, and many have used more than one promotion strategy. The most popular strategy is community engagement, which is used by $69.23 \%$ of participants. This is followed by promotional events and online advertising or social media $(8,61.54 \%)$. Other strategies include the production of print promotional materials, writing scholarly articles, developing collection-specific branding (e.g. logos, slogans, etc.), producing radio programs or podcasts, advertising through the media, and development of promotional film (see fig. 8). Two participants are not doing any promotional work with the local music collection. There were a number of openended responses to the "other" category, including making sure that finding aids are digitized, materials are indexed by Google, producing "online showcases," hosting "in-library concerts," and posting collection content on SoundCloud. 
Figure 8: Promotion strategies

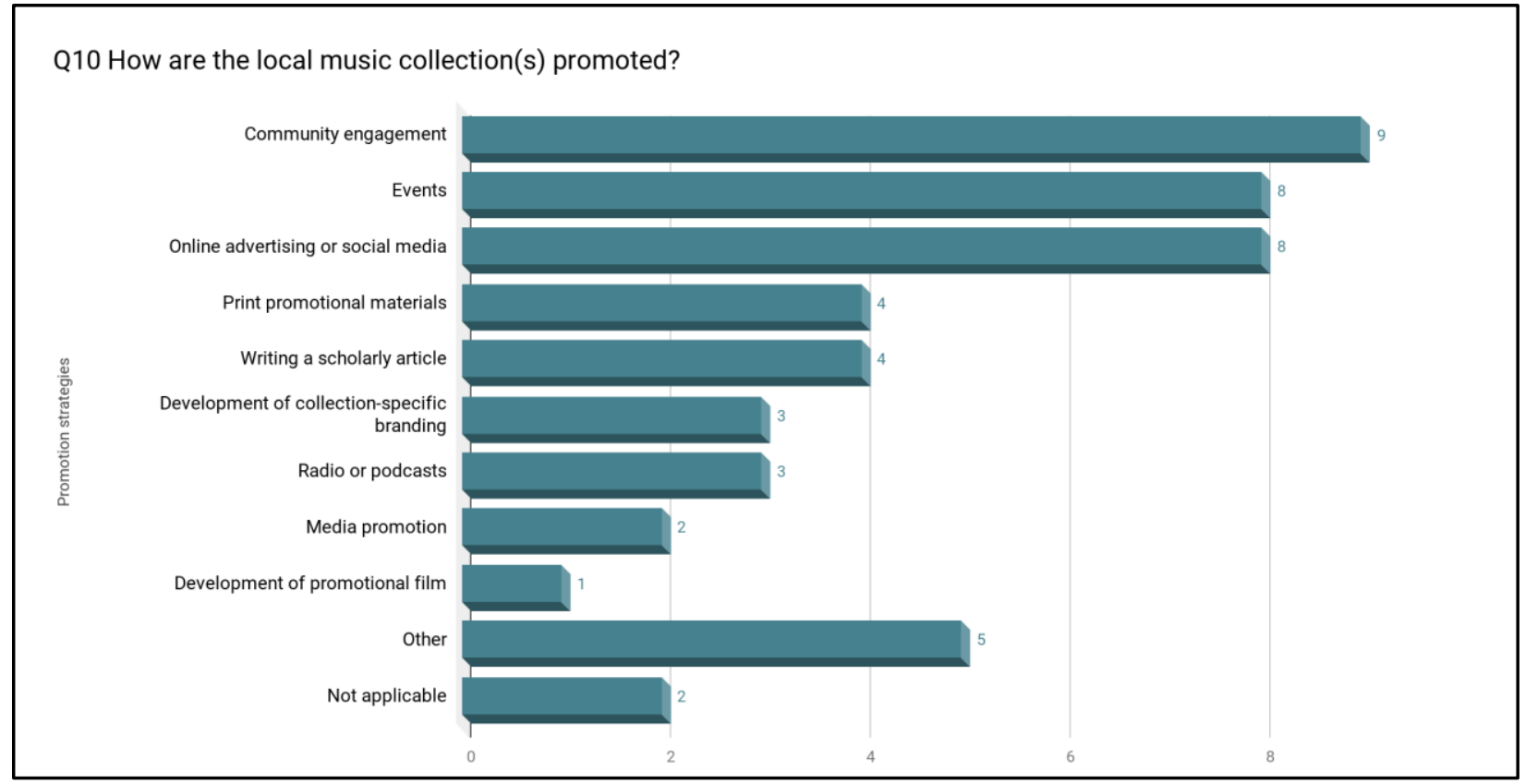

When asked for any additional comments, some participants included details about collecting practices, limitations, and recommendations for practice. Some participants commented on limitations or concerns regarding local music collecting:

"The question of extent will come up, due to eventual storage limitations. Are we trying to collect as comprehensively as possible, or shooting for a representative collection? How often is publicity i.e. a public event/media coverage required to maintain engagement (use and donations)..."

"We do not specialize in collecting local musical archives. It's a big area that costs lots of money and requires expertise that we don't have."

One participant described the role of the library in supporting the local music community beyond collections:

"As a public library our collection is meant to be inclusive of local musicians to help increase their profile. We are also partners in a city-wise [sic] initiative to promote local music."

With regard to the role of community and access, one participant noted:

"Working with the musical community is key to the development of a robust collection. That can be a challenge when the region is so vast, geographically. Hence, digital access is an important aspect of fostering relationships with individuals and communities that are situated great distances from the institution..." 


\section{Key findings}

\section{Defining a scope statement}

Local music collections are diverse and varied in their definitions and limitations, just like the places that they represent. The way collectors choose to word scope statements reflects this. On the one hand, a collection may be limited solely to materials that document the musical activities of a single institution, while another collection may attempt to document all musical activity that took place within a whole province or region.

While each scope statement is particular to its collection, there are elements common to all: place, format, and affiliation (see fig. 9). The place element may indicate a limitation to a geographic area (e.g. province, region, city, or neighbourhood) or a more specific address (e.g. building, venue, or institution). The format element is used to determine which physical or digital formats are included in the collection (e.g. sound recordings, sheet music, concert posters, etc.). The affiliation element describes the nature of the connection between materials and place. These affiliations could include types of people represented (e.g. bands who performed in a particular city or venue, composers who resided in a particular province, etc.), how materials were produced (e.g. CDs distributed by a local music label), and topical content of the materials (e.g. sheet music with references to place names). The place, format, and affiliation elements are sometimes used singularly, and other times in combination to make up scope statements for local music collections.

Practitioners who are developing local music collections at their own institutions may wish to take these elements into consideration when writing collection development policies, considering materials for acquisition, or proposing new local music collections projects.

\section{Figure 9: Elements of local music collection scope statements}

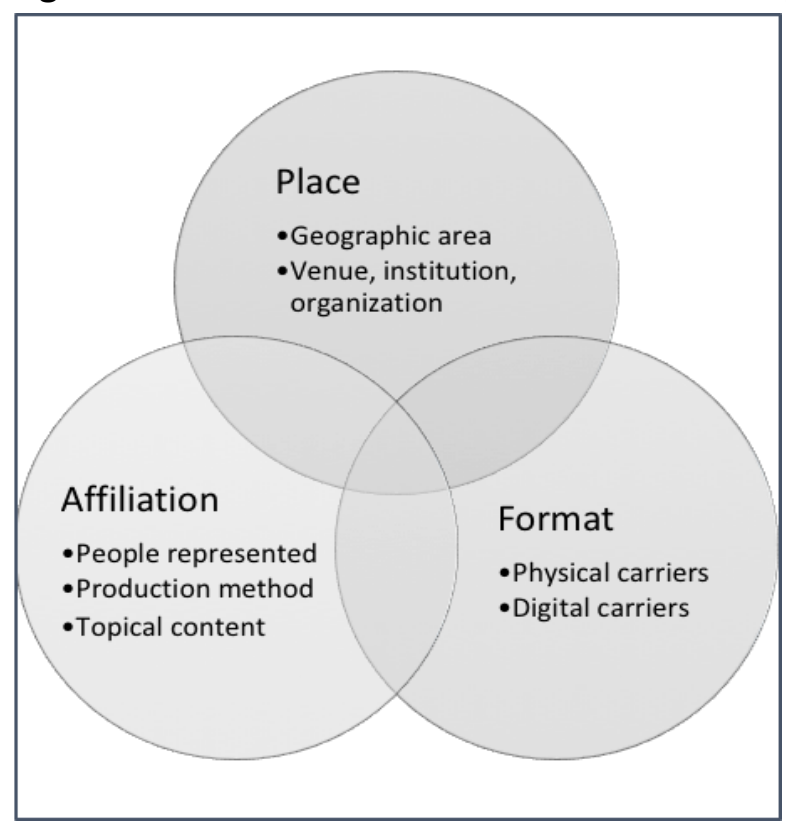




\section{Complexities of practice}

The survey results show that local music collecting is happening across Canada in a variety of library types. The work is complex and multifaceted, due in large part to the range of collection types and musical representations.

While this study is focused on local music collecting in libraries, many of the described collections are actually held alongside archival collections, contain archival materials, or are described using archival standards. This mix of archival and library treatments leads us to conclude that local music collection managers must rely on a wider set of competencies and skills than needed in the development of music collections generally. Most participants are implementing physical and/or digital preservation practices. Similarly, most provide online access to collections.

With regard to collection building, local music collection managers use a wide range of methods for identifying, selecting, and acquiring local music materials. Findings show that work with community members and donors are among the core strategies for building local music collections, although more traditional methods of collection building still remain, such as working with music and library vendors. Relying on community and donors for collection development means that collection managers must establish or build on existing relationships to ensure ongoing support. Outreach and promotion are areas where collection managers are using diverse and creative strategies to build awareness of collections, including community engagement, event hosting, and online marketing.

Practitioners hoping to engage with local music collection work may wish to consider collaborations and partnerships to bring in expertise. Areas of practice where this may be particularly important are donor relations, community engagement or outreach, marketing, digital projects, cataloguing, and archives management.

\section{Community and Relationship-Building}

The concept of 'community' stands out because it impacts all aspects of local music collecting and collections, from descriptions to acquisition processes, use, outreach, and promotion. One of the complexities of the community concept is that it outlines a dual role with regard to local music collecting; the community is both the focus of the collection materials themselves and its creator, in partnership with librarians and other cultural heritage professionals. This dual role presents both challenges and opportunities for collections managers and community members alike. This participant's comment on the topic of providing access illustrates not only the importance of bridging geographic barriers but also the importance of relationship building to ensure collections are used and relevant to community members:

"Working with the musical community is key to the development of a robust collection. That can be a challenge when the region is so vast, geographically. Hence, digital access is an important aspect of fostering relationships with individuals and communities that are situated great distances from the institution." 
The close ties between community and local music collecting invites us to consider how collection managers might choose to engage respectfully with the individuals and communities they work with. ${ }^{22}$ As Kelleher states, "physical and legal custody of records in archives repositories have been central to leveraged and negotiated power among creators, repositories, and users." 23 It is necessary, therefore, for libraries to consider the history of systemic oppression, existing power dynamics, and ongoing injustices that accompany such collecting objectives. We propose a more inclusive approach to community outreach for the purpose of local music collecting. Instead of working with communities for the sole purpose of collecting or documenting their musical history, it is important to consider relationship-building and trust-building as a first step toward further conversation.

The post-custodial model, although applied primarily in archival settings, may serve as a helpful starting place for librarians hoping to work more closely with local music communities, because it "allows communities to maintain ownership of their collections while also receiving institutional support." ${ }^{24}$ The Society of American Archivists defines the post-custodial model as one where "archivists will no longer physically acquire and maintain records, but they will provide management oversight for records that will remain in the custody of the record creators." 25 As Flinn states, this model "addresses the ambivalence that many communities feel towards depositing their archives in formal heritage institutions, but it also avoids the need for professional archivists to make difficult and often upsetting decisions about what is worth depositing and preserving..." ${ }^{26}$ The benefit for libraries who use this model includes closer working relationships, which often lead to stronger and more meaningful outcomes for both the institution and community. Flinn describes this benefit in more detail, highlighting the evolving professional scope of archival institutions:

"One result ... might be that a build up of trust results eventually in direct, permanent responsibility for the archive passing into hands of the formal body, but in other cases the groups will wish to retain direct custody over their archive for the foreseeable future. In this view of professional duties, custody does not determine care and guidance for community collections, but rather such guidance is seen as a part of the community partnership and outreach priorities of the archive service."27

22. Doi, "Local Music Collections in Cultural Heritage Institutions: A Qualitative Systematic Review."

23. Christian Kelleher, "Archives Without Archives: (Re)Locating and (Re)Defining the Archive Through PostCustodial Praxis," Journal of Critical Library and Information Studies 1, no. 2 (July 7, 2017): 24, https://doi.org/10.24242/iclis.v1i2.29.

24. Doi, "Local Music Collections in Cultural Heritage Institutions: A Qualitative Systematic Review."

25. Society of American Archivists, "Postcustodial Theory of Archives," A Glossary of Archival and Records Terminology, accessed August 3, 2018, https://www2.archivists.org/glossary/terms/p/postcustodial-theory-ofarchives.

26. Andrew Flinn, "Community Histories, Community Archives: Some Opportunities and Challenges," Journal of the Society of Archivists 28, no. 2 (2007): 151-76, https://doi.org/10.1080/00379810701611936.

27. Flinn. 
This approach to relationship building serves to benefit both the institution and the community, and building partnerships based on respectful dialogue with local communities will ultimately serve to maintain long-lasting partnerships. Without this communication, we run the risk of alienating the community or building collections that do not accurately represent local narratives and histories.

\section{Limitations}

Although the survey was sent out to a number of institutions and librarians, we did not have access to a comprehensive list of local music collections or collection managers in Canadian libraries. Local music collections are advertised and promoted to varying degrees, which meant it was difficult to ensure that all potential participants in Canada were contacted. There is no way, therefore, to know the number of local music collection managers who did not receive the invitation to participate.

Responses collected are not representative of every province or territory in Canada and regional coverage is inconsistent. Notably, there were no responses in French or from Québec. It is difficult to know whether this is due to the timing of survey distribution, lack of interest, or because local music collecting is happening less in francophone institutions. This survey presents a snapshot in time, and new collections may have been created since it was distributed. New collection management strategies may be in practice by the time this article is published. Conversely, responses do not necessarily represent the work of past collection managers, even though some of the collections are historical in nature.

\section{Next Steps}

While this research is focused on local music collecting in libraries, other types of cultural heritage organizations are also engaged in developing local music collections and working to preserve and document local music histories in Canada. This study was aimed at capturing the professional practices and limitations of practice for librarians working with local music. Findings from this study build a picture of the professional practices currently in use in Canadian libraries. In particular, the open-ended responses also invite further thought on the significance and value of local music collections within the community, as well as their place in national and global music scenes. As part of the next phase of the Sounds of Home project, we will interview collectors across a broader range of organization types, including museums, archives, community organizations, and cultural centres. These interviews will focus less on professional practices and more on the role and consequence of local music collections and collectors within the community. The interviews will address the growing interest in local music topics across a wide range of disciplines, including music librarianship, and will seek to harness the mutual interest in these collections by both the news media and the public.

Responses to Part II of the survey (see Appendix I: Survey questions: English) asked participants to identify other collections in their communities and to share descriptions of their collections publicly. Data from these responses was stored and analyzed separately from the raw survey data in order to 
preserve the anonymity of the responses, but has since been used as a starting point for identifying potential interview participants. Information on collection locations and descriptions has been combined with previously collected data, which will serve as the basis for a publicly available directory of local music collections in Canada. We are also conducting exploratory work using geovisualization techniques to illuminate the relationship between music and place spatially.

There are parallels between the complexity of local music collecting practices and the discourse of music scenes scholarship. For example, the material evidence of local music scenes contained in local music collections is extensive; collections include a wide range of formats that are acquired by various means, representing various parts of a given local scene or scenes in a particular geographic location. Future researchers may wish to dig deeper into this idea of representation as it relates to music scenes, and theorize how local music collections can be imagined as containers of local music scenes.

The survey questions address professional considerations for managing local music collections in libraries and could be easily adapted to survey a different population, such as collectors in another country, geographic region, or a different disciplinary field, such as archives or museums.

\section{Conclusions}

The results of this survey highlight the diversity and complexity of professional practices with regard to local music collections in Canadian libraries. This practice is happening across the country and in a variety of library types. Local music collections themselves are shown to contain a wide range of materials and formats representative of local music communities at institutional, regional, and provincial levels. This diversity in content and description means that different local music collection managers are likely to define local music in different ways. While the local music collections represented in this survey are found in libraries, practices for managing them are derived both from archives and special collections librarianship. Working with local music necessitates strong ties with communities and must depend on strong community engagement and relationship building.

These findings are significant in that they, for the first time, present an aggregated view of this area of local music collection management and music librarianship and a more comprehensive understanding of the nature and extent of local music collections in Canadian libraries. This study will allow us, and others, to further explore ideas about the connection and shifting boundaries among local, national, and global cultures as evidenced in music. 


\section{Acknowledgements}

This research was supported by the Social Sciences and Humanities Research Council of Canada. The survey protocol was tested during the 2018 Annual Meeting of the Music Library Association. Thanks to A. Leach, K. Hujda, S. Lewin-Lane, C. Dow, M. Gilmore, J. Vallier, and S. Outhier who provided valuable time and feedback on the survey design. Thanks to C. Polischuk (University of Saskatchewan) and J. Doiron (University of Alberta) for advice on data cleaning, analysis, and sharing.

\section{Bibliography}

Allen, Lara. "Preserving a Nation's Heritage: The Gallo Music Archive and South African Popular Music." Fontes Artis Musicae, no. 3 (2007): 263.

American Library Association. "Guidelines: Competencies for Special Collections Professionals," July 8, 2008. http://www.ala.org/acrl/standards/comp4specollect.

Baker, Sarah, ed. Preserving Popular Music Heritage: Do-It-Yourself, Do-It-Together. Routledge Research in Music 11. New York: Routledge, 2015.

Baker, Sarah, and Jez Collins. "Sustaining Popular Music's Material Culture in Community Archives and Museums." International Journal of Heritage Studies 21, no. 10 (November 26, 2015): 983-96. https://doi.org/10.1080/13527258.2015.1041414.

Baker, Sarah, Peter Doyle, and Shane Homan. "Historical Records, National Constructions: The Contemporary Popular Music Archive." In Popular Music and Society, 39:8-27. Abingdon, Oxfordshire, United Kingdom: Routledge, 2016.

Belford, Richard. "Building a Regional Music Collection: The Saskatchewan Experience." CAML Review / Revue de l'ACBM 35, no. 1 (2007): 19-22.

Bennett, Andy. "Consolidating the Music Scenes Perspective." Poetics: Journal of Empirical Research on Culture, the Media and the Arts 32, no. 3-4 (2004): 223-34.

- - . "Popular Music and the 'Problem' of Heritage." In Sites of Popular Music Heritage: Memories, Histories, Places, 15-27. Routledge Studies in Popular Music 4. New York: Routledge, 2015.

Berger, Sidney E. "What Is so Rare...: Issues in Rare Book Librarianship." Library Trends 36, no. 1 (1987). http://hdl.handle.net/2142/7513.

Bhattacherjee, Anol. Social Science Research: Principles, Methods, and Practices. Textbooks Collection 3. Global Text Project, 2012. https://scholarcommons.usf.edu/oa_textbooks/3/.

Biddle, Ian D., and Vanessa Knights. Music, National Identity and the Politics of Location : Between the Global and the Local. Ashgate Popular and Folk Music Series. Burlington, VT: Ashgate, 2007. 
Connell, John, and Chris Gibson. Sound Tracks : Popular Music, Identity, and Place. Critical Geographies 17. London: Routledge, 2003.

Dewe, Michael. "Local Studies and Libraries." In Local Studies Collection Management. London: Routledge, 2016.

Dixon, Diana. "From Manuscripts to Metadata: The Changing Face of Local Studies Librarianship." APLIS 24, no. 2 (June 2011): 74-81.

Doi, Carolyn. "Local Music Collections in Cultural Heritage Institutions: A Qualitative Systematic Review." Fontes Artis Musicae 65, no. 4 (2018).

- - . "Local Music Collections: Strategies for Digital Access, Presentation, and Preservation-A Case Study." New Review of Academic Librarianship 21, no. 2 (2015): 256-63. https://doi.org/10.1080/13614533.2015.1022663.

Doi, Carolyn, and Sean Luyk. "Local Music Collections and Collecting in Canada," September 18, 2018. https://doi.org/10.7939/DVN/WAJ9UG.

Epstein, Dena. Sinful Tunes and Spirituals: Black Folk Music to the Civil War. Urbana: University of Illinois Press, 2003.

Epstein, Dena J. "On Collecting Materials for Local Music Histories." Notes: Quarterly Journal of the Music Library Association 24, no. 1 (1967): 18-21. https://doi.org/10.2307/894777.

Fairley, Jan. "The 'local' and 'Global' in Popular Music," 272-89. Cambridge Companions to Music. New York, NY: Cambridge University Press, 2001.

Flinn, Andrew. "Community Histories, Community Archives: Some Opportunities and Challenges." Journal of the Society of Archivists 28, no. 2 (2007): 151-76. https://doi.org/10.1080/00379810701611936.

Gramit, David. "The Transnational History of Settler Colonialism and the Music of the Urban West: Resituating a Local Music History." American Music 32, no. 3 (2014): 272-91. https://doi.org/10.5406/americanmusic.32.3.0272.

Guilbault, Jocelyne. "On Redefining the Local through World Music." In Ethnomusicology: A Contemporary Reader, 137-46. New York: Routledge, 2006.

Hathaway, Edward W. "Developing a State Archive of Local Music Materials." Notes: Quarterly Journal of the Music Library Association 45, no. 3 (1989): 483-94.

Kelleher, Christian. "Archives Without Archives: (Re)Locating and (Re)Defining the Archive Through Post-Custodial Praxis." Journal of Critical Library and Information Studies 1, no. 2 (July 7, 2017). https://doi.org/10.24242/jclis.v1i2.29.

Kmiech, Veronica. "In Other News: The Significance of Canadian Media Sources in an Analysis of Local Music Collection Literature." CAML Review / Revue de l'ACBM 46, no. 1 (2018): 6-16. 
Kruse, Holly. Site and Sound: Understanding Independent Music Scenes. Music/Meanings, vol. 1. New York, NY: P. Lang, 2003.

Leonard, Marion. "Constructing Histories through Material Culture: Popular Music, Museums and Collecting." Popular Music History 2, no. 2 (2007): 147-67. https://doi.org/10.1558/pomh.v2i2.147.

Luyk, Sean. "Scene but Not Heard: Collecting Local Music." CAML Review / Revue de l'ACBM 41, no. 1 (2013): 22-33.

Peterson, Richard A., and Andy Bennett. Music Scenes: Local, Translocal \& Virtual. Nashville, TN: Vanderbilt University Press, 2004.

Rafferty, Michael. "Compiling a Comprehensive Local Music Archive - Some Problems." Local Studies Librarian 20, no. 2 (2001): 12-13.

Society of American Archivists. "Postcustodial Theory of Archives." A Glossary of Archival and Records Terminology. Accessed August 3, 2018. https://www2.archivists.org/glossary/terms/p/postcustodial-theory-of-archives.

Spivacke, Harold. "Collection of Musical Material of Local Interest." Music Library Association Notes, no. 8 (August 3, 1940): 49-54.

Stevenson, Robert Murrell. "Local Music History Research in Los Angeles Area Libraries." InterAmerican Music Review 10, no. 1 (1988): 19-38.

Straw, Will. "Systems of Articulation, Logics of Change: Communities and Scenes in Popular Music." Cultural Studies 5, no. 3 (1991): 368-88.

Vallier, John. "Sound Archiving Close to Home: Why Community Partnerships Matter." Notes: Quarterly Journal of the Music Library Association 67, no. 1 (2010): 39-49.

Wanser, Jeff. "Collecting and Collaborating to Build Community: The Evolution of a Local Music Collection at a Small Liberal Arts College Library." Technical Services Quarterly 31, no. 4 (October 2, 2014): 332-57. https://doi.org/10.1080/07317131.2014.908586.

Winling, Priscilla. "Bringing the Local Music Scene to the Public Libraries Network of Strasbourg: A Live Collection." Fontes Artis Musicae 59, no. 2 (2012): 127-33. http://www.jstor.org/stable/42765570. 


\title{
Appendix 1: Survey Questionnaire, English
}

\author{
Consent \\ You are invited to participate in a research study entitled: Sounds of Home: Exploring Local Music Collections and \\ Collecting in Canada \\ Researcher(s): \\ - Carolyn Doi (Principal Investigator), Assistant Librarian (Music), University Library, University of \\ Saskatchewan, 306966 2433, carolyn.doi@usask.ca \\ - Sean Luyk (Co-Investigator), Digital Initiatives Projects Librarian, University of Alberta Libraries, \\ sean.luyk@ualberta.ca, 780-492-6779
}

\section{Purpose(s) and Objective(s) of the Research:}

This project will seek to understand the state of local music collections across Canada. Specifically, we aim to: identify where collections of local music are held, what music(s) they document, and what evidentiary value they possess; understand the perceived value of collecting local music, and record local music collection management practices currently used by public institutions to determine areas where practices may be improved.

\section{Procedures:}

This research uses a questionnaire, which can be completed online. It is estimated the survey will take no more than 20 minutes to complete. Please feel free to ask any questions regarding the procedures and goals of the study or your role.

\section{Funded by:}

The University of Saskatchewan President's SSHRC Research Fund

The Social Sciences \& Humanities Research Council (SSHRC) Insight Development Grant

\section{Potential Risks:}

There are no known or anticipated risks to you by participating in this research.

\section{Potential Benefits:}

These findings will:

1) benefit music librarians, music libraries, and libraries collecting local music materials by providing strategies for managing local music collections and a comprehensive summary of how local music materials are identified, collected, preserved, and made accessible.

2) be used to identify the location of local music collections in Canada with the goal of providing locational data and collection descriptions in a digital mapping environment.

Please note: Some participants may not see an immediate/direct benefit to participating.

\section{Confidentiality:}

IP addresses and emails are collected but will be removed prior to analysis. The data from part one of the survey (collection scope and collecting practices) will be published and presented, but the data will be reported in aggregate form, so that it will not be possible to identify individual participants. There may be limits to the confidentiality due to context and individual participants may be identifiable because of the size of the sample. The data collected in section two of this survey (Next Steps) will be used to identify the location of local music collections in Canada, and to identify participants for follow up interviews and site visits. Data collected in this section of the survey will not be anonymous. Participants may choose to answer one or both sections of the survey. This survey is hosted by Voxco, a Canadian-owned and managed company whose data is securely stored in Canada. Consider printing this page for your records. 


\section{Storage of Data:}

The data will be stored on password protected computer files at the Social Sciences Research Lab, University of Saskatchewan. The data will be destroyed by electronic file deletion after 5 years of storage. The data from Part One (collection scope and collecting practices) of this study will be archived through the University of Alberta Dataverse, a service that helps researchers publish, analyze, distribute and preserve their data and datasets (https://dataverse.library.ualberta.ca/dvn/). The data will be available to the public and may be used by other researchers in the future.

Right to Withdraw: Your participation is voluntary and you can answer only those questions that you are comfortable with. You may withdraw from the research project for any reason, at any time without explanation or penalty of any sort. Should you wish to withdraw please contact either of the researchers to have your data removed from the study results. Your right to withdraw data from the study will apply until results have been disseminated after June 2018. After this date, it is possible that some form of research dissemination will have already occurred and it may not be possible to withdraw your data.

\section{Follow up:}

Results from this study will be presented at the 2018 Annual Meeting of the Canadian Association of Music Libraries in Regina, SK. Presentation notes will be posted online following the presentation. Survey participants will be notified by email with a link to the presentation notes when they are available.

\section{Questions or Concerns:}

Contact the researchers using the information at the top of page 1; This research project has been approved on ethical grounds by the University of Saskatchewan and University of Alberta Research Ethics Boards. Any questions regarding your rights as a participant may be addressed to those committees through the Research Ethics Offices at ethics.office@usask.ca (306) 966-2975 (out of town participants may call toll free (888) 966-2975) and/or The plan for this study has been reviewed by a Research Ethics Board at the University of Alberta. If you have questions about your rights or how research should be conducted, you can call (780) 492-2615. This office is independent of the researchers.

\section{Consent}

By completing and submitting the questionnaire, YOUR FREE AND INFORMED CONSENT IS IMPLIED and indicates that you understand the above conditions of participation in this study.

\section{Part 1}

\section{Sounds of Home: Exploring Local Music Collections and Collecting in Canada}

\section{Q1 Does your library manage one or more collections of local or regional music?*}

*For the purposes of this research, local music collections are defined as library collections where the scope includes a delimited geographic area (e.g. town, city, neighborhood, province, territory, region, etc).

- Yes

- No

\section{Q2 Where is your library located?}

- Alberta

- British Columbia

- Manitoba

- New Brunswick

- Newfoundland and Labrador

- Nova Scotia

- Ontario

- $\quad$ Prince Edward Island 
- Quebec

- Saskatchewan

- Northwest Territories

- Nunavut

- Yukon

- $\quad$ Other (please specify)

Q3 What type of library do you work in?

- Academic library

- Public library

- Special library

- $\quad$ Other (please explain)

\section{Collection Scope}

Q4 What is the scope of your local music collection(s)?

Q5 What formats are included in your local music collection(s)?

- Sound recordings [45 rpm, 78 rpm, 33 1/3 rpm, CD, reel to reel tape, cassette tape, 8-track tape, born digital, albums, etc.]

- Video recordings

- $\quad$ Notated music [piano roll, score, sheet music, etc.]

- Music manuscripts

- Monographs

- Instructional materials

- $\quad$ Printed ephemera

- $\quad$ Objects [e.g. coasters, buttons, patches, etc.]

- Concert Programs

- Posters

- Photographs

- Other (please specify)

Q6 How are users currently able to access your local music collection(s)? (check all that apply)

- Online

- In person

- Collection is not accessible

- $\quad$ Other (please specify)

Q7 Have items in your local music collection(s) been catalogued?

- Yes

- No

- Partially

Q7a You answered that items in your local music collection(s) are fully or partially catalogued. Is metadata used to indicate that catalogued items are part of a local music collection?

- Yes

- No

- Sometimes

Q7b How is metadata used to indicate that items are part of a local music collection?

- Added name field 
- $\quad$ Added series note

- $\quad$ Added subject headings

Q8 Who are the users of your local music collection(s)? (rank from most frequent to least frequent users. Only select as many as apply) To rank the primary users, drag them into the box on the right (with the most frequent users at the top).

\begin{tabular}{|l|}
\hline Researchers \\
\hline Students \\
\hline Members of the community \\
\hline Visitors from other communities \\
\hline Donors \\
\hline Don't know \\
\hline Other (please specify) \\
\hline
\end{tabular}

Q8a You selected "other", please specify:

Q9 How do your users make use of your local music collection(s)? (select all that apply)

- Scholarly research

- Historical research

- Family research

- Community research

- Teaching

- Don't know

- $\quad$ Other (please specify)

\section{Promotion}

Q10 How are the local music collection(s) promoted? (check all that apply)

- Development of specific branding for the collection(s) (i.e. logo development)

- Community engagement

- $\quad$ Events (e.g. presentations, tables at industry events, conferences, etc.)

- Development of promotional film(s)

- Development of print promotional materials (i.e. posters, pamphlets, brochures, etc.)

- Publications in newspaper/media sources (online or print)

- Online advertising or social media activity (i.e. social media presence, blog, website, etc.)

- Radio or podcasts

- Scholarly article describing the collection(s)

- $\quad$ Other (please specify)

- Not applicable

\section{Collection Development}

Q11 Are new items being added to the local music collection(s)?

- Yes

- No 
Q12 How often do you acquire local music materials from the following sources?

\begin{tabular}{|l|l|l|l|l|l|}
\hline & Never & Rarely & Sometimes & Frequently & Very frequently \\
\hline Individual artists or bands & & & & & \\
\hline $\begin{array}{l}\text { Community based organizations or groups } \\
\text { (e.g. music society, arts organization, } \\
\text { community centre, etc.) }\end{array}$ & & & & & \\
\hline $\begin{array}{l}\text { Music stores or vendors (e.g. online or } \\
\text { physical) }\end{array}$ & & & & & \\
\hline At events & & & & & \\
\hline Donations & & & & & \\
\hline Music label or publisher & & & & & \\
\hline $\begin{array}{l}\text { Creating recordings of oral histories or live } \\
\text { performances }\end{array}$ & & & & & \\
\hline Social media & & & & & \\
\hline Other (please specify) & & & & & \\
\hline
\end{tabular}

Q13 How useful have the following tools or strategies been when identifying and selecting local music for acquisition?

\begin{tabular}{|l|l|l|l|l|l|l|}
\hline & n/a & $\begin{array}{c}\text { Not at } \\
\text { all } \\
\text { useful }\end{array}$ & $\begin{array}{c}\text { Minimally } \\
\text { useful }\end{array}$ & $\begin{array}{c}\text { Somewhat } \\
\text { useful }\end{array}$ & $\begin{array}{c}\text { Useful } \\
\text { useful }\end{array}$ \\
\hline $\begin{array}{l}\text { Establishing or updating a collection } \\
\text { development policy }\end{array}$ & & & & & & \\
\hline $\begin{array}{l}\text { Gathering suggestions through community } \\
\text { engagement activities }\end{array}$ & & & & & & \\
\hline $\begin{array}{l}\text { Gathering suggestions by building or maintaining } \\
\text { community partnerships }\end{array}$ & & & & & & \\
\hline $\begin{array}{l}\text { Keeping or building lists (e.g. spreadsheet, } \\
\text { amazon wish list, etc.) }\end{array}$ & & & & & & \\
\hline $\begin{array}{l}\text { Asking for suggestions from the public through } \\
\text { the media (e.g. newspaper article asking for } \\
\text { donations) }\end{array}$ & & & & & & \\
\hline Conducting research on local music & & & & & & \\
\hline $\begin{array}{l}\text { Selecting from offerings at music stores or from } \\
\text { music vendors }\end{array}$ & & & & & & \\
\hline Getting suggestions (e.g. staff, students, clients) & & & & & & \\
\hline Other (please specify) & & & & & \\
\hline
\end{tabular}

Q14 How are funds to purchase new local music materials secured? (check all that apply)

- Donations from members of the community

- Government funding

- Grants

- From the institution

- A community-based association or organization

- Designated endowment funds

- Other (please specify) 
Q15 What strategies are important when acquiring local music materials? (rank in order of importance from most important to least important. Select only those that apply) To rank the strategies, drag them into the box on the right (most important at the top).

\begin{tabular}{|l|}
\hline Establishing donor agreements \\
\hline Establishing licensing agreements \\
\hline Maintaining flexibility \\
\hline Hosting events to identify or collect local music \\
\hline Promotional activities \\
\hline Advocacy \\
\hline Other (please specify below) \\
\hline
\end{tabular}

Q15a You selected "other", please specify:

Preservation

Q16 Where is the physical location of the local music collection(s) within your institution? (check all that apply)

- Archives or special collections

- Interfiled with other music collections

- Onsite storage

- Offsite storage

- Special collection within a music library

- Other (please specify)

Q17 What steps have been taken to preserve some or all of the collection(s)? (check all that apply)

- Physical preservation

- Digital preservation

- Not applicable

Q18 What steps have been taken to physically preserve the materials in the local music collection(s)?

Q19 What steps have been taken to digitally preserve the materials in the local music collection(s)?

Q20 Is there anything else you would like to add about local music collections or collecting? 


\section{Appendix 2: Survey Questionnaire, French}

Formulaire de consentement du participant

\section{CONSENTEMENT}

*Dans ce questionnaire, le masculin est utilisé sans discrimination, dans le seul but d'alléger le texte.

Nous vous invitons à participer au projet de recherche Sounds of Home: Exploring Local Music Collections and Collecting in Canada (Sons familiers : étudier les collections et la collecte de musique locale au Canada)

\section{Chercheurs:}

- Carolyn Doi (chercheure principale), bibliothécaire adjointe (musique), Bibliothèque de l'Université, Université de la Saskatchewan, carloyn.doi@usask.ca, 306-966-2433.

- Sean Luyk (cochercheur), bibliothécaire responsable des projets numériques, Bibliothèques de l'Université de l'Alberta, Université de l'Alberta, sean.luyk@ualberta.ca, 780-492-6779.

\section{Objectifs du projet de recherche:}

Nous avons pour objectif de dresser un bilan des collections de musique locale partout au Canada et souhaitons plus précisément :

- déterminer à quels endroits se trouvent les collections de musique, ainsi que leur contenu et leur valeur de témoignage;

- comprendre la valeur accordée à la collecte de musique locale;

- consigner les pratiques que les établissements utilisent pour gérer les collections de musique locale et proposer des améliorations, s'il y a lieu.

\section{Procédure:}

Les sondés doivent répondre à un questionnaire qu'ils peuvent remplir en ligne. On estime que 20 minutes suffisent pour le terminer. Pour toute question relative à la procédure et aux objectifs de ce projet de recherche, ou du rôle que vous y jouez, veuillez communiquer avec nous.

\section{Financement:}

- Une subvention d'exploration du Conseil de recherches en sciences humaines (CRSH)

- Une subvention de développement Savoir du CRSH

\section{Risques possibles:}

La participation à ce projet de recherche ne comporte aucun risque connu ou anticipé.

\section{Bénéfices possibles:}

Les résultats du sondage :

- $\quad$ profiteront aux bibliothécaires et aux bibliothèques de musique, ainsi qu'aux bibliothèques qui collectent de la musique locale, car nous leur fournirons des stratégies pour gérer leurs collections de musique locale, ainsi qu'un condensé portant sur l'identification, la collecte et la conservation de ces collections, de même que leur accessibilité.

- $\quad$ seront utilisés pour dresser une description des collections de musique locale au Canada et pour découvrir les lieux où elles sont abritées. Ces renseignements seront intégrés dans une cartographie numérique.

Remarque : certains sondés pourraient ne pas observer de bénéfice immédiat relatif à leur participation.

\section{Confidentialité :}

- Nous recueillerons les adresses IP et courriel des participants, mais elles seront supprimées avant l'analyse.

- Nous publierons et présenterons les données de la première partie du sondage (ayant pour objet l'ampleur des collections et les pratiques en matière de collecte), mais nous en regrouperons les données, de sorte qu'il sera impossible d'identifier les sondés. 
- II se peut toutefois qu'en raison du contexte et de la taille de l'échantillon, on puisse identifier certains participants.

- Nous nous servirons des données récoltées dans la deuxième partie du sondage (Étapes suivantes) pour déterminer où se trouvent les collections de musique locale au Canada, ainsi que pour identifier les participants au projet de recherche, dans le but de les interviewer et de visiter leur bibliothèque. Les données compilées dans cette partie du sondage ne seront donc pas anonymes. Les participants peuvent choisir de remplir une seule partie du sondage, ou les deux.

- Ce sondage est hébergé sur Voxco, une firme détenue et gérée par des Canadiens, dont les données sont archivées de façon sécuritaire au Canada.

- Veuillez imprimer la présente page pour vos dossiers.

\section{Stockage des données:}

- Vos données seront stockées sur des fichiers électroniques protégés par mot de passe dans les Social Sciences Research Laboratories (Laboratoires de recherche en sciences sociales) de l'Université de la Saskatchewan. Elles seront supprimées électroniquement au bout de cinq ans.

- Les données de la première partie du sondage (ayant pour objet l'ampleur des collections et les pratiques en matière de collecte) seront archivées sur le réseau Dataverse de l'Université de l'Alberta. Les chercheurs utilisent ce réseau pour publier, analyser, conserver et disséminer leurs données et ensembles de données (https://dataverse.library.ualberta.ca/dvn/). Les données seront ultérieurement mises à la disposition du public et des chercheurs.

\section{Droit de retirer son consentement :}

Vous prenez part de plein gré à ce projet de recherche et pouvez choisir de ne répondre qu'à certaines questions. En outre, vous pouvez mettre fin à votre participation en tout temps et pour n'importe quelle raison sans vous expliquer ou subir de sanction. Pour retirer votre consentement et faire supprimer vos données du sondage, veuillez communiquer avec l'un des deux chercheurs. Vous aurez jusqu'au mois de juin 2018 pour ce faire. II est possible qu'après cette date, nous ayons déjà disséminé une partie de vos données et que nous ne puissions les supprimer.

\section{Suivi :}

Nous présenterons les résultats de ce sondage lors de l'assemblée générale annuelle de 2018 de l'Association canadienne des bibliothèques, archives et centres de documentation musicaux, qui se tiendra à Regina, en Saskatchewan. Les notes des présentateurs seront affichées en ligne à la fin de leur séance. Les participants recevront un courriel les avisant de la disponibilité des notes et leur fournissant un lien pour y accéder.

\section{Questions et commentaires:}

- Pour toute question ou tout commentaire, veuillez communiquer avec l'un des deux chercheurs dont les coordonnées se trouvent à la page 1.

- Le Bureau d'éthique de la recherche de l'Université de la Saskatchewan a approuvé la dimension éthique de ce projet de recherche. Les sondés peuvent faire parvenir toute question relative à leurs droits à l'adresse : ethics.office@usask.ca ou téléphoner au : 306-966-2975. Les participants de l'extérieur peuvent téléphoner sans frais au : 888-966-2975.

- Le Bureau d'éthique de la recherche de I'Université de l'Alberta a révisé le plan de ce projet de recherche. Pour toute question concernant vos droits ou la procédure de ce projet, veuillez téléphoner au : 780-492-2615. Les chercheurs ne sont pas associés à ce bureau.

\section{Consentement :}

En remplissant et en envoyant ce sondage, VOUS INDIQUEZ VOTRE CONSENTEMENT LIBRE ET ÉCLAIRÉ, et affirmez comprendre les conditions de participation à ce projet. 
Partie 1

Sons familiers : étudier les collections et la collecte de musique locale au Canada

Q1 Votre bibliothèque contient-elle une ou plusieurs collections de musique locale ou régionale*?

*Aux fins de ce projet de recherche, on définit les collections de musique locale comme provenant d'une région géographique particulière (p. ex. ville, village, quartier, province, territoire, etc.)

- Oui

- Non

\section{Démographie}

Q2 Dans quelle province se situe votre bibliothèque?

- Alberta

- Colombie-Britannique

- Île-du-Prince-Édouard

- Manitoba

- Nouveau-Brunswick

- Nouvelle-Écosse

- Nunavut

- Ontario

- Québec

- Saskatchewan

- Terre-Neuve et Labrador

- Territoires du Nord-Ouest

- Yukon

- Autre (préciser)

Q3 Dans quel genre de bibliothèque travaillez-vous?

- Bibliothèque d'un établissement d'enseignement supérieur

- Bibliothèque publique

- Bibliothèque spécialisée

- Autre (expliquer)

\section{Ampleur des collections}

Q4 Quelle est l'ampleur de votre (vos) collection(s) de musique locale?

Q5 Quels formats retrouve-t-on dans votre (vos) collection(s) de musique locale?

- Enregistrements sonores (45 tours, 78 tours, 33 1/3 tours, CD, bobines, cassettes, rubans à huit pistes, albums numériques, etc.)

- Enregistrements vidéo

- Musique transcrite (partitions numériques en bandes, partitions, musique en feuilles, etc.)

- Manuscrits de musique

- Monographies

- Matériel didactique

- Imprimés éphémères

- Objets (p. ex. sous-verres, macarons, badges)

- Programmes de concert

- Affiches

- Photographies

- Autres (préciser) 
Q6 À l'heure actuelle, comment vos usagers ont-ils accès à votre (vos) collection(s) de musique? (veuillez cocher toutes les cases qui s'appliquent)

- En ligne

- En personne

- Notre (nos) collection(s) n'est (ne sont) pas accessible(s)

- Autre (préciser)

Q7 Les objets de votre (vos) collection(s) de musique locale ont-ils été catalogués?

- Oui

- Non

- En partie

Q7a Si vous avez répondu à la question 7 que votre (vos) collection(s) de musique est (sont) cataloguée(s), en partie ou en entier, se sert-on de métadonnées pour indiquer que les objets catalogués font partie d'une collection de musique locale?

- Oui

- Non

- Parfois

Q7b Comment se sert-on de métadonnées pour indiquer que des objets font partie d'une collection de musique locale?

- Nom de champ ajouté

- Note de collection ajoutée

- Vedette-matière ajoutée

- Autre (préciser)

Q8 Qui sont les usagers de votre (vos) collection(s) de musique locale? (Veuillez commencer par les usagers les plus fréquents en faisant glisser cette catégorie dans la case de droite. Ne choisissez que les réponses qui s'appliquent.)

- Chercheurs

- Étudiants

- Membres de la collectivité

- Visiteurs

- Mécènes

- Je l'ignore

- Autre (préciser)

Q8a Si vous avez coché « autre », veuillez préciser :

Q9 Dans quel but vos usagers se servent-ils de votre (vos) collection(s) de musique? (veuillez cocher toutes les cases qui s'appliquent)

- Recherche savante

- Recherche historique

- Recherche familiale

- Recherche communautaire

- Enseignement

- Je l'ignore

- $\quad$ Autre (préciser) 


\section{Promotion}

Q10 Comment fait-on la promotion de votre (vos) collection(s) de musique locale? (veuillez cocher toutes les cases qui s'appliquent)

- Création d'une image de marque pour la (les) collection(s) (p. ex. logo)

- Engagement de la collectivité

- Événements (p. ex. présentations, tables lors de congrès, conférences, etc.)

- Création de films publicitaires

- $\quad$ Création de matériel de promotion (p. ex. affiches, dépliants, brochures, etc.)

- Publications dans les journaux et les médias (imprimés et en ligne)

- Annonces en ligne ou sur les médias sociaux (p. ex. présence sur les médias sociaux, blogues, sites Web, etc.)

- Radio ou balado

- Article savant décrivant la (les) collection(s)

- Autre (préciser)

- Sans objet

\section{Pratiques en matière de collecte}

\section{Q11 Ajoute-t-on de nouveaux objets à votre (vos) collection(s) de musique?}

- Oui

- Non

\section{Q12 À quelle fréquence faites-vous l'acquisition de musique locale des sources suivantes?}

\begin{tabular}{|l|l|l|l|l|l|}
\hline & Jamais & Rarement & Parfois & Fréquemment & Couramment \\
\hline Artistes ou groupes & & & & & \\
\hline $\begin{array}{l}\text { Organismes communautaires } \\
\text { (p. ex. sociétés de musique, } \\
\text { organisations artistiques, centres } \\
\text { communautaires, etc.) }\end{array}$ & & & & & \\
\hline $\begin{array}{l}\text { Magasins ou marchands de musique } \\
\text { (traditionnels ou en ligne) }\end{array}$ & & & & & \\
\hline Lors d'événements & & & & & \\
\hline Dons & & & & & \\
\hline $\begin{array}{l}\text { Éditeurs de musique ou maisons de } \\
\text { disques }\end{array}$ & & & & & \\
\hline $\begin{array}{l}\text { Enregistrements de récits ou de } \\
\text { concerts }\end{array}$ & & & & & \\
\hline Médias sociaux & & & & & \\
\hline Autre (préciser) & & & & & \\
\hline
\end{tabular}

Q13 Les outils suivants vous ont-ils été utiles pour identifier et choisir des collections de musique locale dans le but de les acquérir?

\begin{tabular}{|c|c|c|c|c|c|c|}
\hline & $\begin{array}{l}\text { Sans } \\
\text { objet }\end{array}$ & $\begin{array}{l}\text { Pas du } \\
\text { tout utile }\end{array}$ & $\begin{array}{l}\text { À peine } \\
\text { utile }\end{array}$ & $\begin{array}{l}\text { Un peu } \\
\text { utile }\end{array}$ & Utile & $\begin{array}{l}\text { Très } \\
\text { utile }\end{array}$ \\
\hline $\begin{array}{l}\text { Établir ou mettre à jour une politique } \\
\text { développement des collections }\end{array}$ & & & & & & \\
\hline $\begin{array}{l}\text { Recueillir des suggestions au moyen } \\
\text { d'activités communautaires }\end{array}$ & & & & & & \\
\hline
\end{tabular}




\begin{tabular}{|l|l|l|l|l|l|l|}
\hline $\begin{array}{l}\text { Recueillir des suggestions en créant ou en } \\
\text { entretenant des partenariats } \\
\text { communautaires }\end{array}$ & & & & & & \\
\hline $\begin{array}{l}\text { Se créer ou sauvegarder des listes (p. ex. } \\
\text { tableurs, liste de souhaits sur amazon, etc.) }\end{array}$ & & & & & & \\
\hline $\begin{array}{l}\text { Demander au moyen des médias des } \\
\text { suggestions du public (p. ex. article de } \\
\text { journal sollicitant des dons) }\end{array}$ & & & & & & \\
\hline $\begin{array}{l}\text { Effectuer une recherche sur la musique } \\
\text { locale }\end{array}$ & & & & & & \\
\hline $\begin{array}{l}\text { Parcourir la sélection offerte par des } \\
\text { magasins ou des marchands de musique }\end{array}$ & & & & & & \\
\hline $\begin{array}{l}\text { Recueillir des suggestions (p. ex. personnel, } \\
\text { étudiants, clients) }\end{array}$ & & & & & & \\
\hline Autre (préciser) & & & & & & \\
\hline
\end{tabular}

Q14 Comment vous procurez-vous les fonds nécessaires à l'acquisition de nouvelles collections de musique locale (veuillez cocher toutes les cases qui s'appliquent)

- Dons des membres de la collectivité

- Financement public

- Subventions

- Établissement d'enseignement

- Organisme ou association communautaire

- Fonds de dotation nommé

- Autre (préciser)

Q15 Quelles stratégies comptent le plus pour vous quand il s'agit d'acquérir des objets relatifs à une collection de musique locale? (Veuillez classer en ordre décroissant d'importance en faisant glisser les stratégies dans la case de droite. Ne choisir que les réponses qui s'appliquent.)

- Établir des ententes avec des mécènes

- Établir des licences d'utilisation

- Demeurer flexible

- Organiser des activités dans le but de découvrir de la musique locale et d'enrichir les collections

- Faire la promotion d'activités

- Constituer un groupe de pression

- $\quad$ Autre (préciser ci-dessous)

Q15a Vous avez coché « autre »; veuillez préciser :

\section{Conservation}

Q16 À quel endroit garde-t-on votre (vos) collection(s) de musique au sein de votre établissement? (veuillez cocher toutes les cases qui s'appliquent)

- Archives ou collections spéciales

- Interclassée(s) parmi les autres collections de musique

- Entreposée(s) sur place

- Entreposée(s) ailleurs

- Collection(s) spéciale(s) dans une bibliothèque de musique

- Autre (préciser) 
Q17 Quelles démarches avez-vous entreprises pour conserver toutes les collections ou certaines d'entre elles? (veuillez cocher toutes les cases qui s'appliquent)

- Conservation physique

- Conservation numérique

- Sans objet

Q18 Quelles démarches avez-vous entreprises pour conserver, sur support physique, tous les objets faisant partie de votre (vos) collection(s) de musique?

Q19 Quelles démarches avez-vous entreprises pour conserver, sur support numérique, tous les objets faisant partie de votre (vos) collection(s) de musique?

Q20 Souhaitez-vous ajouter un commentaire relatif aux collections ou à la collecte de musique local 


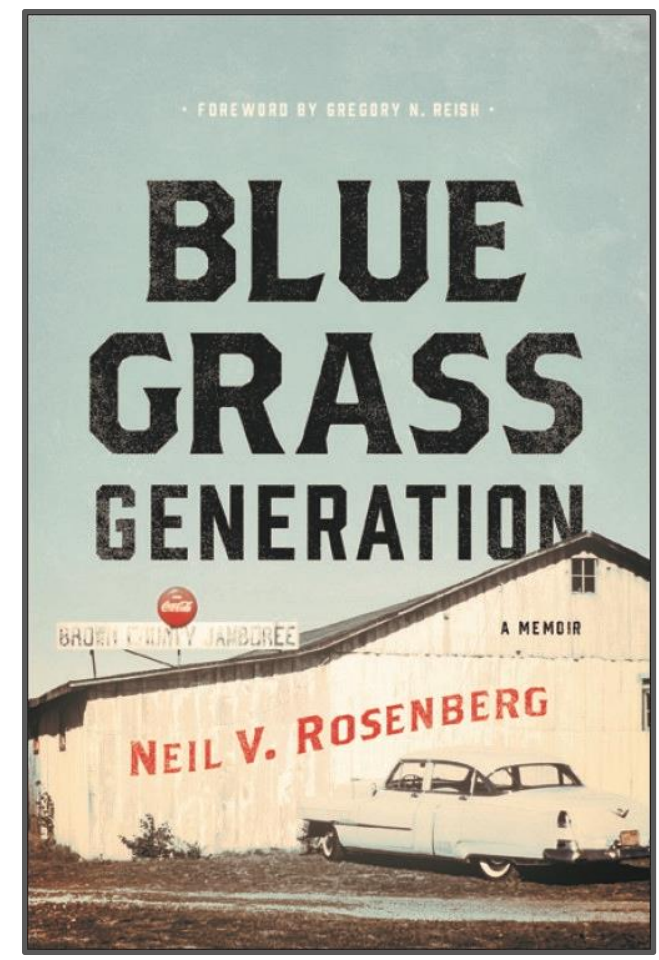

Bluegrass Generation: A Memoir. By Neil Rosenberg. Urbana: University of Illinois Press, 2018. 273 pp. ISBN 9780252083396.

https://www.press.uillinois.edu/books/catalog/ 54aqm8yh9780252041761.html

Reviewed by: Sija Tsai, Independent scholar, Toronto

Bluegrass Generation joins a long list of publications from folklorist Neil Rosenberg, of which his best known is perhaps his Bluegrass: A History, a book that was reissued in 2005, twenty years after it first appeared. ${ }^{1}$ In the decades following its original publication, other scholars have written about various sociocultural and industry-related aspects of bluegrass but Rosenberg's historical monograph remains an invaluable resource for information on the genre's early development. ${ }^{2}$

The present memoir can function as a natural companion to Bluegrass: A History. Readers will still absorb a great deal of historical information about the genre (particularly pertaining to the 1960s), but with the added benefit of Rosenberg's eyewitness accounts.

In terms of scope, Bluegrass Generation covers the author's youth and undergraduate years in various locales, his time as a budding bluegrass musician, his research activities, and later his experiences at Bill Monroe's Bean Blossom Jamboree. The latter was a country music park in Bean Blossom, Indiana, in which a weekly series of performances took place. After two years of performing regularly at the Jamboree, Rosenberg was engaged as a manager of the event during the summer of 1963.

1. Neil Rosenberg, Bluegrass: A History (1985; rev. ed., Urbana: University of Illinois Press, 2005).

2. See, for example, Mark Finch, "Bill Monroe, Bluegrass Music, and the Politics of Authorship," in The Cambridge Companion to the Singer-Songwriter, ed. Katherine Williams and Justin A. Williams (Cambridge: Cambridge University Press, 2016), 43-54; Robert Cantwell, "Believing in Bluegrass," in The Bluegrass Reader, ed. Thomas Goldsmith (Urbana: University of Illinois Press, 2004), 202-211; and Mark Fenster, "Alison Krauss and the Contemporary-Traditional Conflict in Modern Bluegrass," in All That Glitters: Country Music in America, ed. George H. Lewis (Bowling Green, Ohio: Bowling Green State University Popular Press, 1993), 317-328.

\section{(7) (5)

This work is licensed under a Creative Commons Attribution-NonCommercial 4.0 International License. 
Many music scholars are accustomed to sifting through musician biographies written for the general populace. Thus to some, it may be an unusual experience to read an autobiographical memoir composed with an historian's eye for detail and fieldworker's penchant for collecting and record-keeping. While many writers of memoirs may draw from old letters, Rosenberg uses them extensively to build a chronological history of where he was at key points in time, sometimes week by week. Life's little moments are presented in painstaking detail, and even when Rosenberg discusses his teenage years, the tone is one of careful documentation rather than rebellion or teenage angst.

We learn about the friends he jammed with, the spaces in which he performed, the music stores he frequented, and the albums he acquired. We also get to know in which year each album entered his life, and how it shaped his bluegrass activities. An instrument buff, Rosenberg also pays special homage to his gear. We learn, for example, about the broken Gibson mandolin which he turned over to John Duffey (of The Country Gentlemen) to repair, and, later, about the flathead Gibson banjo which lacked the prewar style neck he pined for. ${ }^{3}$

As the memoir progresses from Rosenberg's early research studies and creative collaborations to his time at the Bean Blossom Jamboree, we come to understand his triple identity as a performer, academic, and arts administrator-and at various points we see some of these identities coalesce.

For example, he provides a recollection of early performances at Bean Blossom where he shared the stage with musicians Shorty and Juanita Shehan. At the time, much was made of his identity as a student: "Shorty often mentioned that I was a graduate student at IU...Although most of the other people who worked at the Jamboree also had occupations other than music, they were never identified on stage as plumbers, salespersons, factory workers, shop owners, or truck drivers." (p. 28) Being the only Indiana University student, and especially a student in folklore (a term Rosenberg says was unfamiliar to the Bean Blossom audience), made him a curiosity. He was able to get around this through his knowledge of sports: "I'd been raised in a sporting family...Being able to chat about sports with people at Bean Blossom was much easier than talking about my interests in music as a folklorist. That helped me fit in." (p. 28)

As his network expanded, Rosenberg used his contacts from Bean Blossom to complement his academic endeavours. For example, he tells of how his association with mandolinist Jesse Fender led him to meet many local fiddle makers and thus helped him to develop a research question on local fiddle-making traditions. Rosenberg's navigation of his contrasting identities

3. The Country Gentlemen was a US bluegrass band that was active from the late 1950 s through the early 2000s. 
may thus resonate with scholars interested in the tension between "insider" and "outsider" status that often presents itself in ethnography. ${ }^{4}$

However, researchers from other areas of music scholarship will also find useful material in this memoir. Rosenberg's tenure at the Brown County Jamboree coincided with the 1960s North American folk revival. The author recounts his interactions with Ralph Rinzler, and the growing acceptance of bluegrass into the campus folk music scene and broader folk festival circuit. ${ }^{5}$ This gradual shift was not without tension, as scholars of the folk revival can appreciate (see, for example, pp. 134-35).

The audience for this book, then, need not be limited to bluegrass scholars and enthusiasts. Students of ethnomusicology may find it invaluable as an informal guidebook for ethnography. Readers who are dual musician-scholars or arts administrator-scholars will appreciate the synergy between Rosenberg's research, creative and industry activities. And of course, Rosenberg's personal recollections are a source of ethnographic material in their own right and may benefit researchers of other areas who have an interest in North American music or the 1960s in general.

4. See, for example, James Kippen, "Working With the Masters," in Shadows in the Field: New Perspectives for Fieldwork in Ethnomusicology, 2nd ed., ed. Gregory Barz and Timothy J. Cooley (New York: Oxford University Press, 2008), 125-40.

5. Ralph Rinzler was a musician, folklorist, promoter, and co-founder of the Smithsonian Folklife Festival. He was best known for his contributions to the North American folk revival. 


\section{Piryoerylk Chopin}

a life and times

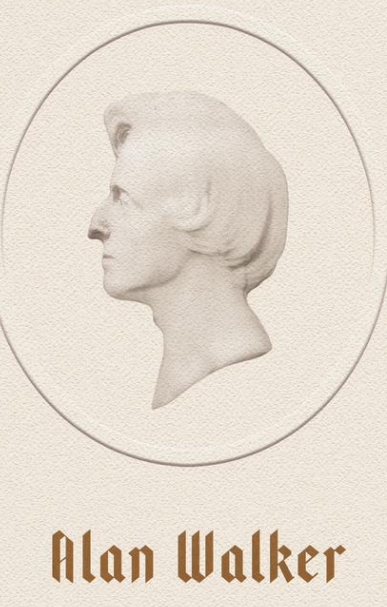

Fryderyk Chopin: A Life and Times. By Alan Walker. New York: Farrar, Strauss and Giroux, 2018. 727 pp. ISBN 9780374159061.

\section{https://us.macmillan.com/books/9780374159061}

Reviewed by: Jolanta Pekacz, Dalhousie University

Over a hundred biographies of Frederic Chopin have been published since his death in 1849, some two dozen of them in this century alone, and any new biographer faces a challenge to justify his entry into this crowded field. It is not clear what prompted Alan Walker to write a monumental volume of over 700 pages. It could not have been scholarship produced in "recent years" pertaining to George Sand, by which Walker means Georges Lubin's edition of Sand's letters completed in 1995 and Sand's biography by Curtis Cate

published in 1975 (p. 8), as these sources have been used by Chopin scholars for decades. Similarly, biographical information about Chopin's friends and teachers from Warsaw can be found in the existing biographies and online reference sources (e.g., NIFC). ${ }^{1}$ In the end, Walker has only weasel words to justify his enterprise: "the times are generally absent from the story of Chopin's life" creating "the void ... waiting to be filled" and those cataclysmic events "are given short shrift in the many sanitized versions of Chopin's life ..." (p. 19).

To his credit, Walker consulted some recently published Polish sources clarifying details of Chopin's early life, e.g., the dating of Eliza Radziwiłł's drawing of Chopin in Antonin in 1829 (p. 101), and his correct spelling of Polish names is commendable. At the same time, however, recent scholarship reinterpreting aspects of Chopin's biography is largely absent from his book. In fact, Walker rarely mentions contributions of other authors, which makes him appear as a pioneer conqueror of a terra incognita of Chopin's life and leads to a compilation of the existing scholarship without due references (exs., the circumstances of Catherine the Great's death in 1760 on p. 58 n. 17; the story of Astolphe Custine on p. 304; information on the Polish exiles in Paris in 1830 on p. 216; the account of the cholera epidemic in April 1832 on p. 228; quotation on p. 299 attributed to "one popular biographer" instead of a specific author). To make the

1. The website of the Fryderyk Chopin Institute (http://en.chopin.nifc.pl/institute/)

\footnotetext{
This work is licensed under a Creative Commons Attribution-NonCommercial 4.0 International License.
} 
story flow, anecdotes known from older biographies take up space along with trivia and lengthy digressions (exs., the issue of Solange Sand's real father, pp. 360ff; Liszt's affair with Marie Pleyel, p. 322 n. 2; or the fate of the piano Chopin used in Valldemosa, p. 389 n. 32).

Walker's attempt to provide a broader historical context consists of inserting information collected from reference sources and surveys into the biographical narrative. Such method rarely produces new insights; more specific sources would have to be used to illuminate decisions and motivations of the main protagonists beyond what we already know. Further, information Walker provides is not free from errors. For example, Nicolas Chopin could not fear conscription into Napoleon's army in 1790 (p. 24), had he returned to France, because no such army existed at that time and conscription was not introduced until 1793. There was no "Warsaw Uprising" in 1830-1831 (p. 180 and elsewhere) but a November Uprising. There was no "King Louis-Napoleon" (p. 611) - Louis-Napoleon was President of the Second Republic and then Emperor. It is not true that Napoleon "attacked and took Moscow" in 1812 (p. 26) Moscow was deserted when Napoleon arrived. And if 4,500 francs was a "very large sum" in 1849 (p. 623) how could 6,142 francs be a "moderate sum" (p. 628) at the same time?

Retelling Chopin's life story with a few new details and background information may easily take up 700 pages but is not likely to forge new ways of looking at Chopin. In fact, Walker's biography effectively reinforces the existing clichés, including those that have already been questioned: about Chopin being "fully formed" by the time he left Poland; about his "close" rapport with the Polish aristocracy; about his connections with the Polish circles in Paris; or about his frequent appearances in the salons. To these, Walker adds a portion of anachronisms reflecting preoccupations of present-day academia, rather than nineteenth-century reality: about Chopin's anti-Semitism, his allegedly insincere conversion forced by Fr. Jelowiecki, the priest's questionable integrity, or George Sand's rebelliousness being a result of her three-year stay in a convent as a young girl. The certainty with which Walker "knows" these things and confidence with which he states his opinions is a reminder that no evidence is needed or doubt allowed in the political correctness department.

Finally, the readability of the book is hampered by the use of cryptic acronyms in the footnotes, not only for the frequently quoted sources (such as Chopin's correspondence) but for all of them. An alphabetical listing of these acronyms at the end of the book does not correspond to an alphabetical order of authors' names, which makes the same author appear in different places, and the list an unhelpful substitute for the missing bibliography. 


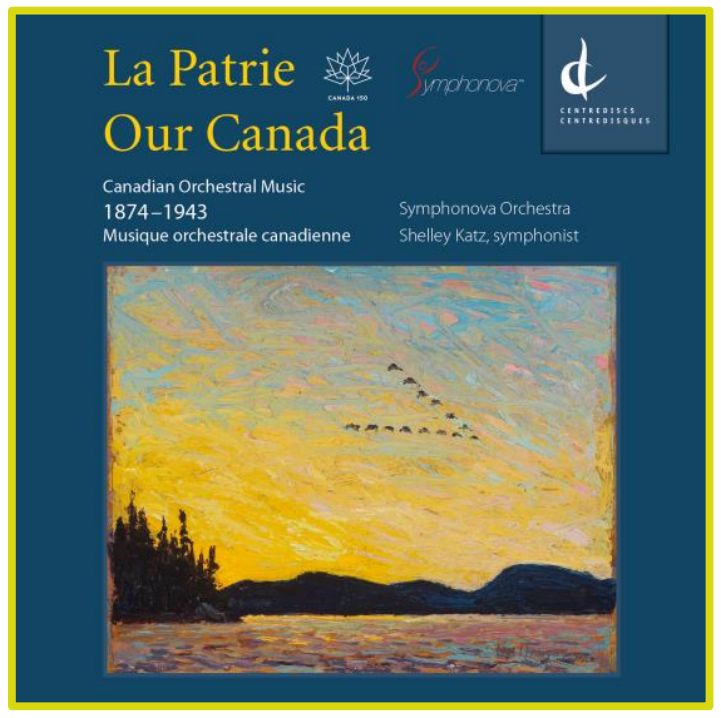

La Patrie / Our Canada: Canadian Orchestral Music

1874-1943. Symphonova Orchestra, Shelley Katz,

Symphonist. Toronto: Centrediscs CMCD 25618, 2018. 1 compact disc (76:05). La Patrie / Calixa Lavallée (12:54) Overture Macbeth / Clarence Lucas (14:14) - Trois

Préludes / Rodolphe Mathieu (6:21) - Overture / Ernest MacMillan (11:59) - Pavane / Georges-Émile Tanguay (3:34) - Serenade for Strings / Murray Adaskin (9:09) Capriccio for Hand Timpani / Violet Archer (4:40) - Our Canada (Music for Radio No. 1) / John Weinzweig (12:41).

https://www.musiccentre.ca/node/152550

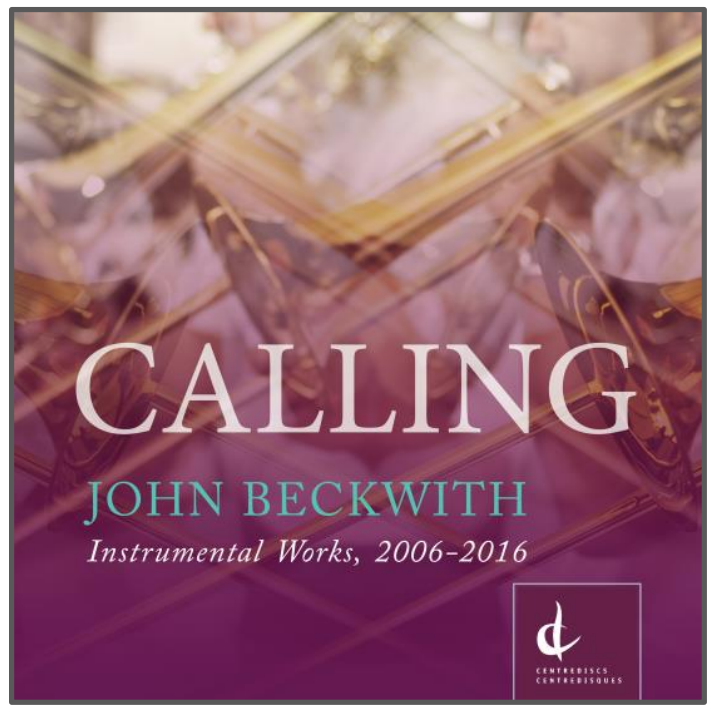

\section{Calling: John Beckwith Instrumental Works / Oeuvres}

instrumentals, 2006-2016. Various Performers. Toronto: Centrediscs CMCCD 24917, 2018. 1 compact disc. Calling (8:26) - Fractions (12:25) - Follow Me (11:06) - Pages (5:12) - Sonatina on "Mari's Wedding" (6:06) - Ut re mi fa sol la: Six Fantasies for Guitar (15:38) - Quintet (10:23). http://www.musiccentre.ca/node/150918

Reviewed by: J. Drew Stephen, University of Texas at San Antonio

The conditions under which contemporary classical music is currently produced present many challenges for composers and performing arts ensembles. The ease of access to existing music through streaming platforms creates massive competition for any new composition or recording while production costs make it prohibitive to use the large orchestral forces that were once summoned by Mahler and Bruckner as a matter of course. As I previously observed in a 2014 review of four contemporary Canadian music recordings, ${ }^{1}$ to succeed in this environment, it is necessary to find innovative ways to present music so that it has a sense of purpose, a sense of legitimacy, and a sense of relevancy grounded in time and place. Colin Eatock, who has also addressed this issue in an article

1. J. Drew Stephen, "Canadian Contemporary Music in the Twenty-First Century: A Review of Four Recordings," CAML Review 42, no. 2 (2014): 36-40, https://caml.journals.yorku.ca/index.php/caml/article/view/39544/35853.

This work is licensed under a Creative Commons Attribution-NonCommercial 4.0 International License. 
assessing the state of classical music, argues that the goal for "musicians, educators, concert presenters, and all others involved in the promotion of classical music" should be "to bring classical music back into the everyday lives of everyday people." ${ }^{2}$ The two recordings under consideration here provide excellent examples of this approach.

The Symphonova Orchestra's release of eight Canadian symphonic works written between 1874 and 1943 on La Patrie / Our Canada corresponds with Canada's Sesquicentennial year and is a fitting contribution to these celebrations. Since these works, according to the Canadian Music Centre's press release, "have not been previously recorded on $\mathrm{CD}$ and [are] rarely performed," ${ }^{3}$ they fill an important gap in our recorded heritage of symphonic music. With selections by some of Canada's most significant composers of the past 150 years, the repertoire has clear purpose and relevance. These are works that define the country and should have been available long before now.

While the recording of this repertoire is clearly welcome, it is the ensemble itself that is most remarkable. From what I can tell-the exact details are not clear in the liner notes or on the ensemble's website-the group consists of twelve solo musicians augmented by orchestral samples from the Vienna Symphonic Library. The dynamics and tempo of the sampled material are coordinated with live musicians through gestures from the conductor. This unusual setup, according to Symphonova Orchestra's website, allows the group to specialize "in repertoire that would normally require large forces playing in large spaces" and to reach "where no normal symphonic complement can usually go." In other words, the group addresses head-on the challenge of bringing a symphonic repertoire to venues and communities that could not normally afford or accommodate a full symphony orchestra. I found it frustrating that descriptions of how this is accomplished rely heavily on jargon. In rendering these performances, the "acoustics of the venue itself is transformed by the Symphonova Virtual Acoustic System $^{\mathrm{TM}}$ (SVAS ${ }^{\mathrm{TM}}$ )" which somehow creates "the best concert hall acoustics even in the least likely venues." The music played by individual musicians is augmented by "specialist unique Instrumental Loudspeakers made out of the instruments themselves, whose speed, dynamics and playing style is seamlessly controlled by Symphonova's newly developed conducting wand." Even the ensemble director, in his role of coordinating sampled material and live musicians, is re-designated as a "symphonist" rather than a conductor. Given the innovative nature of these performances, I would have preferred a clearer explanation of how they were achieved.

While Symphonova's aim "to promote high quality but forgotten repertoire, perhaps ignored for practical, financial or political reasons" is certainly laudable, the recorded product is not entirely convincing. Listening to the recordings, even with quality headphones, I found the overall sound lacking in depth, with some of the instruments-notably the percussion-displaced spatially in the mix. While most of the full orchestra passages are realistic, I found that some orchestral effects sounded fabricated. An example is the stopped horns and pizzicato strings passage starting at 2'10" in the Overture Macbeth

2. Colin Eatock, "What's Wrong with Classical Music?” 3 Quarks Daily (Monday, October 4, 2010), http://www.3quarksdaily.com/3quarksdaily/2010/10/whats-wrong-with-classical-music.html.

3. Canadian Music Centre, “La Patrie - Our Canada," accessed February 10, 2019, https://www.musiccentre.ca/node/152550. 
by Clarence Lucas. The Symphonova technology is clearly impressive, but commercial recording may not be its best application. It seems to me that a recording could be more easily and more effectively produced using multi-tracking and mixing technology. Even in a concert setting-and this is my impression from watching the videos on the Symphonova website-I suspect that the effect of hearing a full symphonic work performed by a small group of musicians would be uncanny and disappointing. One loses the visually impressive spectacle of a large group of coordinated individuals working together to produce a coherent symphonic product.

Despite the claim in the press release that these works have not been previously recorded, there is in fact a commercial release of Ernest MacMillan's Overture on Symphonic Spectaculars performed by the Toronto Symphony under the direction of Andrew Davis. ${ }^{4} \mathrm{~A}$ comparison of the two recordings reveals the shortcomings of the Symphonova performances. Whereas the Symphonova recording sounds flat and lacking in nuance, the full orchestral recording by the Toronto Symphony is rich, dynamic and much more vibrant. It is clear that modern technology makes it possible for Symphonova to perform large orchestral works in small spaces, but it does not replace the grandeur of a full symphony orchestra.

A different response to the economic challenges of presenting contemporary music in the twenty-first century can be seen in John Beckwith's Calling. This release consists of seven instrumental chamber works written between 2006 and 2016 and serves as a companion to Avowals (Centrediscs, CMCCD 12907) released in 2007 and featuring works for solo voice written between 1980 and 2000. Together the two releases demonstrate a trend towards chamber compositions that can be economically produced in small venues.

Even without the sonic resources of a large ensemble, Beckwith achieves brilliant and imaginative explorations of timbre and texture in these short instrumental pieces. They also demonstrate Beckwith's keen interest in a wide range of musical styles and compositional approaches. Fractions, which is scored for a Carrillo piano-a keyboard instrument consisting of ninety-seven pitches covering a single octave rising from middle-C-and a string quartet with two of the instruments tuned a quarter-tone higher than the others, allows for wonderful explorations of micro tuning to produce effects that shimmer with colour. Calling, written for an ensemble of flugelhorn, trombones, euphonium, and double bass recalls the historical associations of the trombone as a signal instrument while the Quintet is written for a mixed instrumentation in the tradition of Pierrot Lunaire and L'Histoire du soldat. The other pieces are responses to various models that demonstrate Beckwith's curiosity and broad musical interests: Follow Me for clarinet and piano consists of canonic formulations inspired by Bach's Goldberg Variations, Pages is a suite of condensed piano miniatures, Ut re mi fa sol la for guitar is a set of six fantasies on different hexachord patterns in the spirit of the late Renaissance instrumental pieces, and the Sonatina on "Mairi's Wedding" is built on fragments of the popular Scottish tune. Beckwith notes that, having heard "Mairi's Wedding" at the annual Tartan Ball hosted by the Toronto branch of the Royal Scottish Country Dance Society, it "proved so catchy I couldn't get it out of my head."

4. Ernest Macmillan, conductor, Symphonic Spectaculars - Grands Moments Symphoniques, recorded 1988, CBC SM-5068. This recording was later released in digital format as CBC SMCD-5068. 
What makes this recording particularly compelling is the quality of the performances. The performers on these recordings are seasoned and respected musicians who, in most cases, have a direct personal connection to Beckwith. In his liner notes, Beckwith specifically recognizes Robert Aitken and William Aide-who were both students in his University of Toronto music classes fifty years ago-as "valued friends whose performances and promotion of my music I have greatly appreciated." This familiarity extends to the other performers as well: pianist Barbara Pritchard is a devotee of Canadian keyboard music and a regular performer of Beckwith's compositions; the guitar fantasies were commissioned for Peter Higham who also commissioned, premiered, and recorded Beckwith's After-images After Webern for guitar and violoncello; Follow Me was composed at the request of clarinetist Peter Stoll who has collaborated with Beckwith on several previous compositions; and composer Bruce Mather, who performs the Carrillo piano on Fractions, was the person who introduced Beckwith to this unusual instrument. As a result, the performers are personally invested in the music and it shows in the sincerity of their interpretations. In fact, these are definitive recordings by the performers for whom the pieces were written and performances from events that are significant in Beckwith's career: Pages and Fractions are live recordings of the premiere performances, Calling and the Quintet are premier performances from a live concert organized by New Music Concerts in honor of Beckwith's 90th birthday, and Follow $\mathrm{Me}$ is a live performance from the 90th Celebration of John Beckwith concert at the University of Toronto. Even with the ambient noise that is occasionally audible, these are vibrant recordings that capture the excitement of the live concerts.

Although the approaches demonstrated on these two recordings are very different, both realize the goal of bringing classical music back into the everyday lives of everyday people. In La Patria / Our Canada, the Symphonova Orchestra makes innovative use of digital technology to perform overlooked symphonic works that are relevant to Canada's Sesquicentennial celebrations. Due to the nature of the ensemble, it should be possible to bring these and other similar pieces to remote communities that would not normally have access to symphony concerts. The superb liner notes by Elaine Keillor demonstrate the importance of these works and provide details that help the listener understand the music and appreciate its significance. In Calling, John Beckwith offers vibrant explorations of sound and colour in works for instrumental chamber ensembles. More important, the recordings demonstrate the human relationships among the composer, the performers, and the audiences. These are compositions that emerged from Beckwith's personal connections to performers and performances that preserve a distinct sense of time and place. With these recordings that celebrate the past-150 years of Canadian symphonic music and John Beckwith's remarkable career as a composer spanning 60 years-we are also given models for the future production of Canadian classical music. 


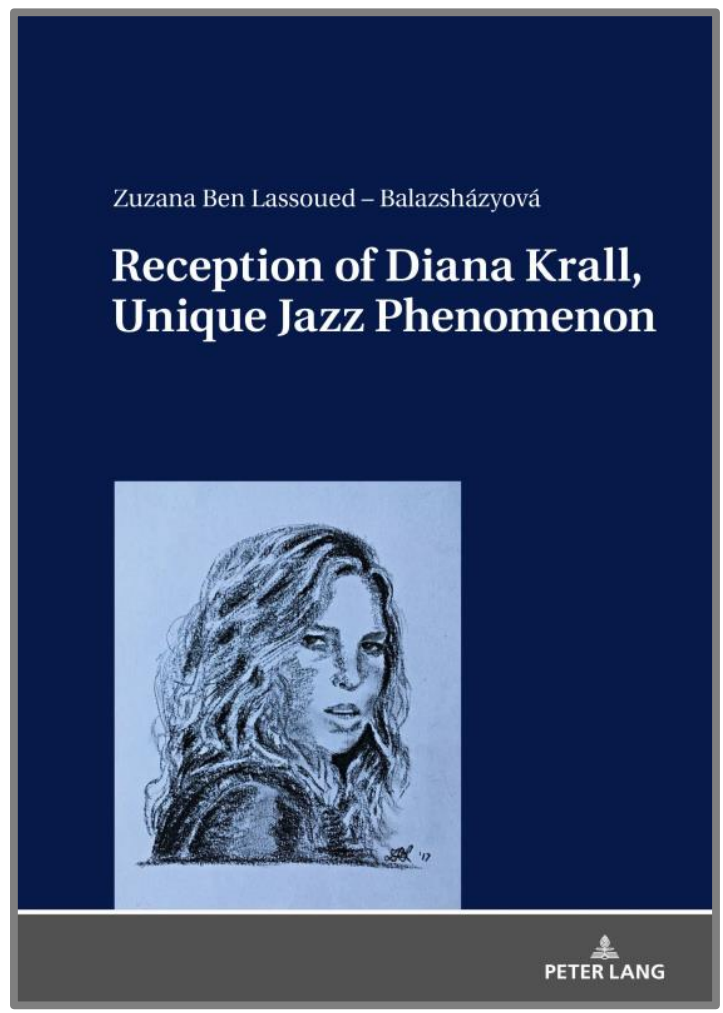

Reception of Diana Krall, Unique Jazz Phenomenon. By Zuzana Ben Lassoued-Balazsházyová. Berlin: Peter Lang, 2018. 189 pp. ISBN 978-3631745755.

https://www.peterlang.com/abstract/title/67487

Reviewed by: Rob van der Bliek, York University

Diana Krall's debut album, Stepping Out (1993), is a delightful venture, more illustrative of her piano playing than her vocals, but at least in 1993 you could say that her piano playing was more interesting than her vocals. She has a light, playful touch on the album, charmingly unpredictable in her ideas and effortlessly drifting in and out of synch with her rhythm section, who leave lots of space for her. Eight years later, The Look of Love (2001) finds her engulfed in Claus Ogerman's over-the-top arrangements and studio production, her piano playing subsumed, her vocals enhanced and her image recast into a diva lounging in stiletto heels. If there ever was a topic suitable for reception history in jazz then surely the transformation of Diana Krall would be one. The question is, as the title of this book suggests: is she a unique jazz phenomenon? Probably not, but she is a very successful one.

Krall grew up in British Columbia, was recognized as a prodigy, and attended Berklee on a scholarship, followed by a stint in Los Angeles and eventually landed in Toronto (where she recorded her debut album for Justin Time) and New York. Her career has been continuously ascendant and diverse, collaborating with Elvis Costello (her husband), T-Bone Burnett, and Tony Bennett. She has won Grammy and Juno awards, has had numerous albums firmly lodged in the Billboard charts, and has received the Order of Canada.

Zuzana Ben Lassoued-Balazsházyová's book is based on her PhD dissertation obtained at Comenius University in Bratislava, Slovakia. Krall's ethnic background is Slovakian, and the author is keen to demonstrate connections that enhance a narrative that places her in a specific cultural context by tracing her family's roots, even going so far as to reproduce a facsimile of

This work is licensed under a Creative Commons Attribution-NonCommercial 4.0 International License. 
Krall's great grandmother's birth certificate (b. 1884). How this is relevant to Krall's music remains unclear as there is no discernable musical connection between Krall and Slovakia. The book opens with what seems to be a manifesto of sorts, with sections titled "Sociological reasons for complete understanding of music" and "Aesthetical, philosophical and musical factors leading to a complete understanding of music," riddled with antiquated and uninformed assertions about art and society. We are left with the impression that all of this somehow is necessary to justify either the scholarly intent of the work or the integrity of Krall's music, or both. Either way, it doesn't do Krall justice.

The bulk of the book is about comparisons between Krall and other jazz performers. A case in point is the comparison drawn between Coltrane and Krall (pp. 27-30), based on their respective use of microtonal inflections derived from Indian music, in which the real issue seems to be the impossibility of notating the inflections that most jazz performers use; Coltrane clearly was listening to Indian music and emulating aspects of it, but I doubt that Krall was or is doing the same. Similarly, Ben Lassoued-Balazsházyová sets up a number of incongruous and tenuous connections between Krall and Bill Evans, Oscar Peterson, Bud Powell, Teddy Wilson, McCoy Tyner, and Art Tatum. For example, in the section on Bill Evans, she offers the following analysis: "However, her subdued style does not sound impressionistic [whereas Evans does], but rather mysterious (but not blurry) and calm in a more punctuated style with less or no pedal, not related to any musical period but by her own style" (p. 67). (All of the transcriptions used in the comparisons, incidentally, have no copyright clearance statements, and have been taken from published transcriptions, albeit "transcribed and rewritten in Finale," as indicated in the verso.) And confoundedly: "The major difference between Diana Krall and Art Tatum is that Art Tatum was unpredictable due to his tendency to change keys multiple times within a phrase whereas Diana Krall's style is easier to anticipate because she does not use many key changes or chord substitutions like Tatum" (p. 95).

Perhaps the most tenable connection is between Krall and Nat "King" Cole, but not necessarily framed as pianistic; again, here the analytical language is wanting: "Cole plays with a lighter 'hoppy-bouncy' touch with higher arch in his hand and more rounded fingers that Diana which makes his piano solos crystalline. Diana's hands were also bouncy initially but not light due to her intended punctuation" (p. 63). An analysis of Krall's vocal technique is plagued with dubious assertions about jazz singing in general and the various abilities of performers to be able to sing and play at the same time: "Therefore, singers such as Sarah Vaughan or Andy Bey have difficulties with piano because their first developed instrument was the voice, not a piano. Although Sarah Vaughan started playing piano at the age of 7, she never developed it to the level that Diana did." (p. 108) In other words, what makes Krall stand out is her ability to do both. By itself this is not an unusual or bold assertion but you are left with the impression that someone like Sarah Vaughan is an inferior musician, which is clearly not the case. 
The analytical terminology used in the book is idiosyncratic and ideologically motivated, at least in the sense that Ben Lassoued-Balazsházyová's mission is to demonstrate Krall's artistic merits in light of the criticism she-not surprisingly-receives for her more commercially-oriented albums. The book clearly is a proclamation by the author of the value and integrity of Krall's music. As a revised dissertation published by an academic publisher it parades as musicological analysis (roughly two-thirds of the book deals with comparing transcriptions of her and others' music), which could add legitimacy or weight to that proclamation, but because of its shortcomings ends up undermining it. Aside from the numerous grammatical errors there is an insularity to the arguments presented, with solecistic terminology supporting them. Examples abound: "music autonomy" as a standard of musicianship (pp. 36-40); "popvocal-jazzpiano style" and "anti-rubato tempo" (pp. 103-4) as terms for describing the mix of popular music and jazz and phrasing. And in one of the more peculiar turns that the book takes, a quote from Bill Clinton describing his experience as a musician needing to interpret what is written on the page becomes the inspiration for a banal polemic titled "Music beyond music sheets." The book ends with a conclusion that it has "analyzed a relationship of multicultural environment, and solved the problem of identity and integrations of diaspora into a new macro and micro-environment" (p. 175). You get the picture.

Had this book been self-published I would not have felt the need to harp on its faults, as it is clear to me that Ben Lassoued-Balazsházyová is a knowledgeable piano teacher who is passionate about Diana Krall and sees it as her mission to promote Krall through establishing the legitimacy of her music. There is nothing wrong with that. What is wrong is that the publisher, Peter Lang, has let this work be published without any evidence that it has been reviewed by peers, let alone competent copy editors. 


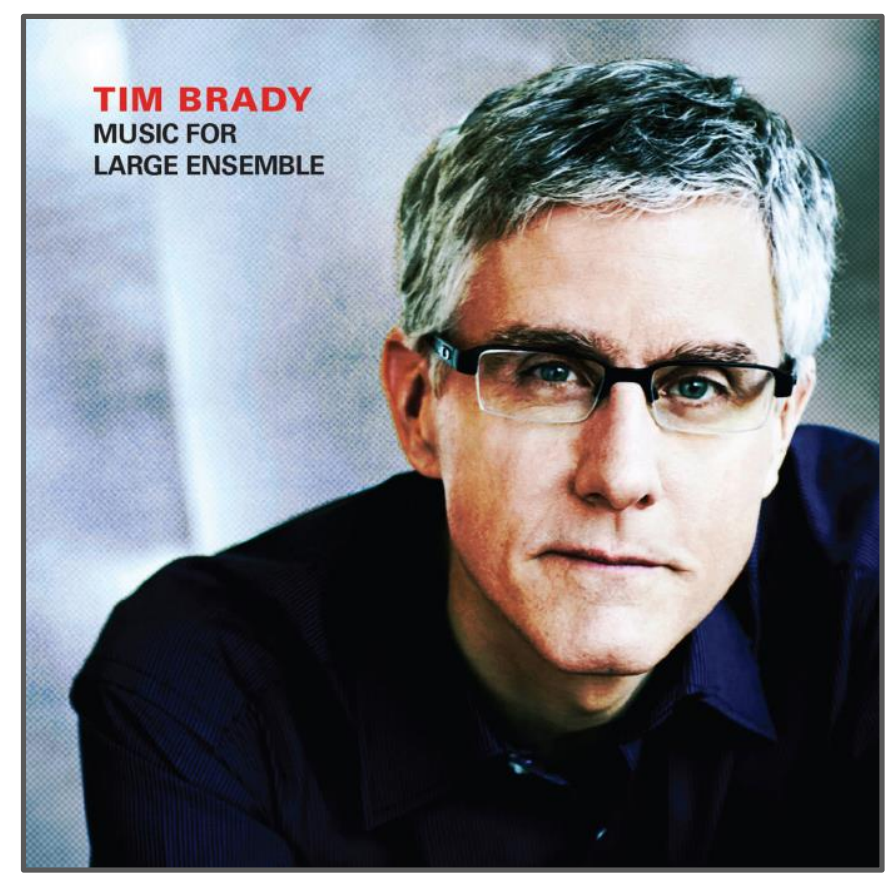

Tim Brady: Music for Large Ensemble. Boulder, CO: Starkland ST-230, 2018. 1 compact disc (63:59). Contents: Désir: Concerto for Electric Guitar and Large Chamber Ensemble / Tim Brady, electric guitar, Bradyworks Large Ensemble, Cristian Gort, conductor (26:07) - Eight Songs About: Symphony \#7 / text: Douglas Smith; Sarah Albu, soprano, Vincent Ranallo, baritone, Bradyworks Large Ensemble, Tim Brady, conductor (37:44).

https://starkland.bandcamp.com/album/ tim-brady-music-for-large-ensemble

Reviewed by: Alastair Boyd, University of Toronto

One sunny day last June in a lofty arcade near Toronto's business district, passersby may have been surprised to encounter a slim, silver-haired figure thrashing away on an electric guitar, with a back-up band of four dozen more guitars making the rafters ring. Quite a few of the spectators had certainly made a special effort to be in the neighbourhood, because they knew that Canadian composer and guitarist Tim Brady had been commissioned by Toronto's Luminato Festival for a work celebrating what would have been George Harrison's seventy-fifth birthday. The result was the piece they were hearing: While 100 Guitars Gently Weep - Concerto for George. However, for many in the crowd this event was probably their first exposure to Brady's music. Those who went on their way resolving to become better acquainted with his compositions will find no shortage of recordings to choose from: the discography on his website (timbrady.ca) lists more than twenty, from his earliest, jazz-based CDs to this latest disc on the Starkland label.

The stylistic span of these recordings illustrates the disparate roots of Brady's musical personality as both composer and performer. He initially studied the guitar and composition at Concordia University in Montreal (where he was born in 1956) after which he obtained a Master's degree in jazz performance and composition at the New England Conservatory. Settling in Toronto in 1980 he quickly achieved success as a composer, winning several CAPAC

This work is licensed under a Creative Commons Attribution-NonCommercial 4.0 International License. 
composition awards, and getting commissions from Arraymusic and New Music Concerts. These "Toronto period" works display the modernist style characteristic of that era. During these years it was as if he maintained separate musical identities and pursued parallel careers as jazz guitarist and composer. But gradually the electric guitarist and the composer came together. By the time he returned to Montreal in 1987 and founded "Bradyworks," his own instrumental ensemble and production company, his new course was clearly set.

In their contrasts, the two works on this new CD showcase the eclectic nature of Brady's style, aptly described in the booklet as "a highly personal synthesis of contemporary classical, jazz, rock, and electronics." Désir: Concerto for Electric Guitar and Large Chamber Ensemble (20162017) is Brady's third concerto for his instrument, and demonstrates his continuing preoccupation with the challenges of combining amplified and acoustic music, and bridging what in the liner notes he calls the "cultural gap between electric guitar and orchestra." Formally the work follows the traditional three-movement "fast-slow-fast" concerto structure. The first movement, entitled "Ecstasy," has a vigorous rhythmic character based on the constant repetition of rapid 16th-note descending scale figures of varying lengths, for both soloist and ensemble. There are some abrupt shifts to contrasting slower sections, but the relentless hard-driving pulse always quickly reasserts itself. Throughout, the texture is motivic and linear with much rhythmic unanimity between instruments, so that very little in the way of harmonic motion is created.

The slow second movement- "Beauty" - offers an opening cloud of electronically tinged instrumental colours, followed by the first emergence of melodic solo guitar lines over a chordal instrumental accompaniment. It leads straight into "Wisdom," the third movement, which in effect reconciles the two stylistic poles presented in the previous movements. Although there is a return to rapid guitar figurations alternating with patterns from the ensemble, the texture is considerably more diatonic and chordal than was the case with the first movement. The feel is thus closer to experimental rock than New Music minimalism: think Frank Zappa channelling The Rite of Spring.

For the second work on the disc, Eight Songs About: Symphony \#7, Brady exchanges his guitar for the conductor's baton. The title has a double meaning, as Brady not only calls the work his Seventh Symphony, but in it pays homage to Dmitrii Shostakovich's Seventh Symphony and the circumstances of its premiere in Leningrad in August 1942 during the 900-day siege. The original text for this cycle of songs for soprano and baritone is by Brady's frequent collaborator Douglas Smith. In each song the voice represents a different person associated with the Shostakovich premiere. For example, baritone Vincent Ranallo opens and closes the cycle with the songs "Bells" and "August 9th," which are similar in their New Music vocal style-recitative- 
like vocal lines over outbursts of instrumental commentary that seem disconnected from the voice-although the first represents Stalin and the last, conductor Karl Eliasberg.

In her three solos (songs \#2, 5, and 6) soprano Sarah Albu assumes first the voice of Shostakovich's wife Nina Varzar, then the voice of a prostitute, and finally that of the Leningrad Radio Orchestra's second bassoonist. This sixth song, "Aria," is the most straightforward, with a chordal accompaniment and even some voice-instrument doublings, reflecting the text in which the bassoonist proclaims "I prefer simple music." Further exceptions to the predominant New Music style are song \#4 ("Distance"), the other solo for baritone, which features a jazz-like accompaniment as a German soldier speaks wonderingly of hearing distant music from the besieged city; and the second of the two duets, "Performance," where the Leningrad orchestra's two oboists sing in lyrical unison of their struggles with Shostakovich.

The work certainly bears out Brady's admission in the notes that he has been "at times, a bit obsessed with the life and music" of Shostakovich; but unlike the disc's preceding concerto, there is nothing overtly symphonic about the form of these songs, the title notwithstanding. As for the Concerto for George I mentioned at the outset: it is well worth checking out the video from last June on YouTube. There is a link to this on Brady's website, where you can also learn about his other recent recordings, and discover more about this distinctive figure in Canadian music. 